THE DIALOGUE BETWEEN THE INTELLECTUAL PROPERTY PROVISIONS IN PREFERENTIAL TRADE AGREEMENTS AND THE BRAZILIAN LEGAL FRAMEWORK

\author{
Master Dissertation \\ Advisor: Associate Professor Dr. Alberto do Amaral Júnior
}

UNIVERSITY OF SÃO PAULO

LAW SCHOOL

São Paulo - SP 



\section{Linhares Mesquita, Alebe}

The Dialogue Between The Intellectual Property Provisions in Preferential Trade Agreements and the Brazilian Legal Framework / Alebe Linhares Mesquita ; orientador Alberto do Amaral Júnior -- São Paulo, 2017. 269

Dissertação (Mestrado - Programa de Pós-Graduação em Direito Internacional) Faculdade de Direito, Universidade de São Paulo, 2017.

1. Preferential Trade Agreements. 2. TRIPS-Plus. 3. Patent. 4. Test Data. 5. Brazil. I. do Amaral Júnior, Alberto, orient. II. Título. 


\section{ACKNOWLEDGMENTS}

To my parents, Arlan and Valéria, for their commitment to my education, for encouraging my dreams and for not measuring efforts to see me happy; and to my sister, Alessa, for all the love and friendship.

To Professor Alberto do Amaral Júnior, with special esteem and gratitude, for the substantial contribution to my academic trajectory, for the wise lessons and guidance and for the true example that we can overcome all obstacles to achieve our dreams no matter how difficult they may seem.

To Professor Vera Thorstensen, my sincere gratitude, for the opportunity to join her team as legal researcher at the CGTI/FGV; for the motivation, enthusiasm and continuous support to my carrier; and for introducing me to the intellectual property world.

To Professor Michelle Ratton Sanchez Badin and Professor Cristiane Lucena Carneiro, for the valuable review, suggestions and insightful comments in my qualification exam. They were very important to the final result of the present work.

To all the Professors, Thomas Cottier, Felix Addor, Daniel Arbix, Ely Caetano Xavier Júnior, Manfred Elsig, Germana Belchior, Rodrigo Polanco, for taking their precious time to discuss particular aspects of the development of the present work.

To the research team of the Center for Global Trade and Investment Studies (CGTI) of the Getulio Vargas Foundation (FGV/SP), for the enriching research environment, stimulating discussions and all the fund that we had while working together.

To the Ryoichi Sasakawa Young Leaders Fellowship Fund (SYLFF), for granting the scholarship that help me in the conclusion of the present work.

To my colleagues from the University of São Paulo, Bruno Pegorari, Belisa Eleoterio, Mariana Boer, Mauro Arima, Stephanie Scandiuzzi, Viviana Palacio, Vivian Rocha, for the friendship and the discussions that allowed me to improve the present work. To my friends, Tathiane Faria, Emanoel Cruz, Jana Maria Brito, Leopoldo Gutierre, Marco Duarte, who have supported me along the years of master's degree in São Paulo.

To Sonia Haramura and Hélio Bertoldi Filho, for the hospitality and for making me feel at home during all my years in São Paulo.

To Martin Girsberger and Mathias Schäli, who provided me an opportunity to join their teams in the Swiss Federal Institute of Intellectual Property; and for all the colleagues that made this experience not only professionally but also personally enriching. My sincere gratitude.

To the World Trade Institute, Margrit Vetter, Federica Cristani, for the amazing time as visiting research fellow. Thank you Jenny Surbeck for all the mind-blowing conversations on the problematic that pervades this work and for helping me with the DESTA Database.

To my Swiss family, Markus, Barbara, Lukas and Dominic Schmid, for all the support during my time back in Berne; and for always accompanying my journeys with great joy. 
Alebe Linhares Mesquita. The Dialogue Between the Intellectual Property Provisions in Preferential Trade Agreements and the Brazilian Legal Framework. 2017. 269 p. Master Faculty of Law, University of São Paulo, São Paulo, 2017.

\begin{abstract}
The present work promotes a dialogue between the intellectual property provisions adopted in Preferential Trade Agreements (PTAs) and the Brazilian legal framework. In recent years, PTAs have become a major source of international intellectual property regulation. This happens in parallel to the multilateral trading system and rules established under the auspices of the World Trade Organization (WTO). The new intellectual property provisions established under PTAs advance significantly the rules established under the WTO Agreement on Trade-Related Aspects of Intellectual Property Rights (TRIPS Agreement). In this scenario, Brazil is apart from the international economic trend of adopting intellectual property provisions in PTAs. Due to its inaction, the country cannot influence the direction in which the international intellectual property regulation is heading. This issue is analyzed in the light of the balance between private and public interests that the protection of intellectual property rights imposes. The general objective of the present work is to investigate how and to what extent the intellectual property rules established under PTAs differs from the Brazilian intellectual property regime. The specific objectives are to assess which are the legal issues and the possible effects that pervade the adoption higher standards of intellectual property protection in PTAs; to map and analyze the norms on patent and test data protection adopted in PTAs and to compare them with the TRIPS Agreement and the Brazilian intellectual property regime; and to investigate how intellectual property rules are diffused across international, regional and national levels. The methodology adopted in this research is characterized as bibliographic, descriptive and exploratory. The importance of this research resides in understanding the cross cutting trends in the establishment of new intellectual property rules. This work concludes that the intellectual property rules on patent and test data protection accorded under PTAs do not radically differ from the Brazilian intellectual property regime. Brazil already has several provisions in its national legislation that even exceed the level of patent and test data protection required under these PTAs and the TRIPS Agreement. On the one hand, the Brazilian intellectual property regime differs from the following TRIPS-Plus provisions on: patentability of methods of treatment, plants and animals; limitation of the grounds for compulsory license; restriction of the grounds for patent revocation; adjustment to compensate the curtailment of the patent term due to the marketing approval procedures; patent-linkage; and test data exclusivity of pharmaceutical products for human use submitted to marketing approval. On the other hand, the Brazilian intellectual property regime aligns with the following TRIPS-Plus provision: prohibition of parallel importation of patented products; patentability of "new uses" of known compounds; adjustment in the patent term of protection to compensate unreasonable delays in the granting process; disclosure of the origin of the national genetic resource and associated traditional knowledge in patent applications; test data exclusivity of pharmaceutical products for veterinary use and plant protection products.
\end{abstract}

Key Words: Preferential Trade Agreements. TRIPS-Plus. Patent. Test Data. Brazil. 
Alebe Linhares Mesquita. O Diálogo entre os Dispositivos de Propriedade Intelectual nos Acordos Preferenciais de Comércio e o Quadro Jurídico Brasileiro. 2017. 269 p. Mestrado Faculdade de Direito, Universidade de São Paulo, São Paulo, 2017.

\section{RESUMO}

O presente trabalho promove um diálogo entre as disposições sobre propriedade intelectual adotadas nos Acordos Preferenciais de Comércio (APCs) e o regime jurídico brasileiro. Nos últimos anos, os APCs se tornaram uma fonte importante de regulação internacional da propriedade intelectual. Isso acontece paralelamente ao sistema e as regras multilaterais de comércio estabelecidas sob os auspícios da Organização Mundial do Comércio (OMC). As novas disposições em matéria de propriedade intelectual estabelecidas no âmbito dos APCs avançam significativamente as regras estabelecidas no Acordo da OMC sobre Aspectos dos Direitos de Propriedade Intelectual Relacionados ao Comércio (Acordo TRIPS). Nesse cenário, o Brasil está à parte da tendência econômica internacional de adotar disposições sobre propriedade intelectual em APCs. Devido à sua inação, o país não pode influenciar a direção que a regulação internacional da propriedade intelectual se dirige. Essa questão é analisada à luz do equilíbrio entre os interesses privados e públicos que a proteção dos direitos de propriedade intelectual impõe. O objetivo geral do presente trabalho é investigar como e em que medidas as normas sobre propriedade intelectual estabelecidas em APCs diferem do regime de propriedade intelectual brasileiro. Os objetivos específicos são avaliar as questões legais e os possíveis efeitos que permeiam a adoção de padrões mais elevados de proteção da propriedade intelectual em APCs; mapear e analisar as normas sobre proteção de patentes e dados de teste adotadas em APCs e compará-las com o Acordo TRIPS e com o regime de propriedade intelectual brasileiro; e investigar como as regras de propriedade intelectual são difundidas nos níveis internacional, regional e nacional. A metodologia adotada nesta pesquisa é caracterizada como bibliográfica, descritiva e exploratória. A importância desta pesquisa reside na compreensão das tendências transversais no estabelecimento de novas regras de propriedade intelectual. Este trabalho conclui que as normas de propriedade intelectual sobre proteção de patentes e dados de teste acordadas nos PTAs não diferem radicalmente do regime de propriedade intelectual brasileiro. O Brasil já possui várias disposições em sua legislação nacional que até mesmo excedem o nível de proteção patentes e dados de teste exigido por esses APCs e pelo Acordo TRIPS. Por um lado, o regime de propriedade intelectual brasileiro difere dos seguintes dispositivos TRIPS-Plus sobre: patenteabilidade dos métodos de tratamento, plantas e animais; limitação dos motivos para licença compulsória; restrição dos motivos para revogação de patentes; ajuste para compensar a redução do prazo de patente devido aos procedimentos de aprovação para comercialização; vinculação entre patente e aprovação comercial; exclusividade de dados de teste de produtos farmacêuticos para uso humano submetidos à aprovação comercial. Por outro lado, o regime de propriedade intelectual brasileiro alinha-se com os seguintes dispositivos TRIPS-Plus sobre: proibição de importação paralela de produtos patenteados; patenteabilidade de "novos usos" de composições já conhecidas; ajuste no prazo de proteção de patente para compensar atrasos injustificados no processo de outorga; divulgação da origem dos recursos genéticos nacionais e do conhecimento tradicional associado nos pedidos de patente; exclusividade de dados de teste de produtos farmacêuticos para uso veterinário e produtos para proteção de plantas.

Palavras-Chave: Acordos Preferenciais de Comércio. TRIPS-Plus. Patente. Dados de Teste. Brasil. 
Alebe Linhares Mesquita. Le Dialogue entre les Dispositions sur La Propriété Intellectuelle dans les Accords Commerciaux Préférentiels et le Cadre Juridique Brésilien. 2017. 269 p. Master - Faculté de Droit, Université de São Paulo, São Paulo 2017.

\section{RÉSUMÉ}

Cette étude développe un dialogue entre les dispositions relatives à la propriété intellectuelle adoptées dans les Accords Commerciaux Préférentiels (ACPs) et le régime juridique brésilien. Ces dernières années, les ACPs sont devenus une source majeure de la réglementation internationale de la propriété intellectuelle. Ce, parallèlement au système et aux règles multilatérales du commerce établies sous les auspices de l'Organisation Mondiale du Commerce (OMC). Les nouvelles dispositions en matière de propriété intellectuelle établies dans le cadre des ACPs avancent précisent considérablement les règles énoncées dans l'Accord de l'OMC sur les Aspects de Droits de Propriété Intellectuelle qui touchent au Commerce (l'Accord ADPIC). Dans ce schéma, le Brésil s'écarte de la tendance économique internationale qui adopte des dispositions sur la propriété intellectuelle dans les ACPs. De part son retrait, le pays ne peut influer l'orientation de la réglementation internationale de la propriété intellectuelle. Cette question est analysée à la lumière de l'équilibre entre les intérêts privés et publics que la protection des droits de propriété intellectuelle impose. L'objectif général du présent travail est d'examiner comment et dans quelle mesure les règles de propriété intellectuelle établies dans le cadre des ACPs diffèrent du régime brésilien de la propriété intellectuelle. Les objectifs spécifiques sont d'évaluer les questions juridiques et les potentiels effets qu'entraine l'adoption de normes de protection de la propriété intellectuelle plus élevées dans les ACPs; de cartographier et d'analyser les normes sur la protection des brevets et des données d'essai adoptées dans les ACPs pour les comparer avec l'Accord ADPIC et le régime brésilien de propriété intellectuelle; et d'examiner comment les règles de propriété intellectuelle sont diffusées aux niveaux international, régional et national. La méthodologie adoptée pour cette recherche fut à la fois bibliographique, descriptive et exploratoire. L'importance de cette recherche réside dans la compréhension des tendances transversales dans l'établissement de nouvelles règles de propriété intellectuelle. Ce travail conclut que les règles de propriété intellectuelle sur la protection des brevets et des données d'essai convenues dans les ACPs ne diffèrent pas radicalement du régime brésilien de la propriété intellectuelle. Le Brésil a déjà plusieurs dispositions dans sa législation nationale qui dépassent même le niveau de protection des brevets et des données d'essai requises par ces ACPs et par l'Accord ADPIC. Le régime brésilien de la propriété intellectuelle diffère des dispositions ADPIC-Plus suivantes : la brevetabilité des méthodes de traitement, des plantes et des animaux ; la limitation des motifs pour la licence obligatoire; la restriction des motifs pour la révocation de brevet; l'ajustement pour compenser la réduction de la durée du brevet en raison des procédures d'approbation de commercialisation; le lien entre brevet et approbation commerciale; et l'exclusivité des donnés d'essai des produits pharmaceutiques à usage humain soumis à l'approbation de commercialisation. En revanche, le régime de propriété intellectuelle du Brésil s'aligne sur les dispositions ADPIC-Plus suivantes : l'interdiction de l'importation parallèle de produits brevetés; la brevetabilité des «nouvelles utilisations » de composés déjà connus ; l'ajustement de la durée de la protection du brevet pour compenser les retards injustifiables dans le processus de délivrance; la divulgation de l'origine de la ressource génétique nationale et des connaissances traditionnelles associées dans les demandes de brevet; et l'exclusivité des donnés d'essai des produits pharmaceutiques à usage vétérinaire et de produits de protection des plantes.

Mots-Clés : Accords Commerciaux Préférentiels. ADPIC-Plus. Brevet. Donnés d'Essai. Brésil. 


\section{LIST OF TABLES}

Table 1 - List of PTAs Including Substantial Patent and Test Data Provisions signed from

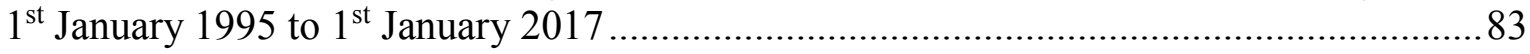

Table 2 - Exhaustion of Patent Rights (Parallel Importation) ......................................... 98

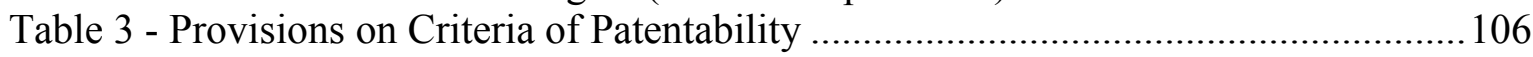

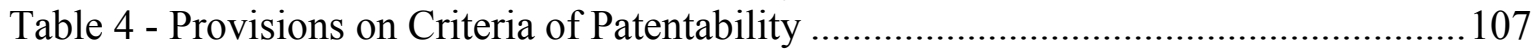

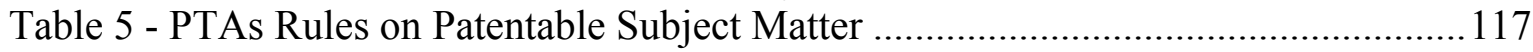

Table 6 - PTAs Rules on Patentable Subject Matter ......................................................... 118

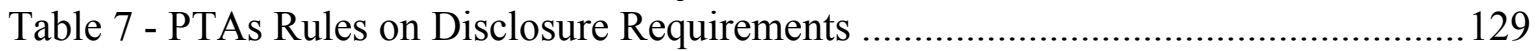

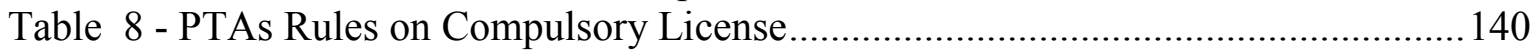

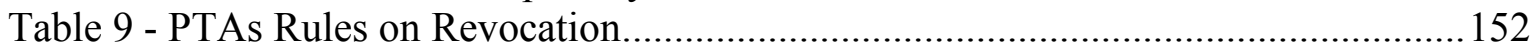

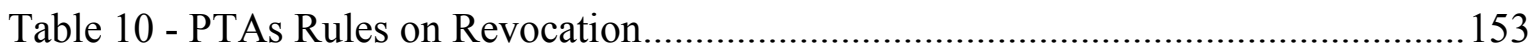

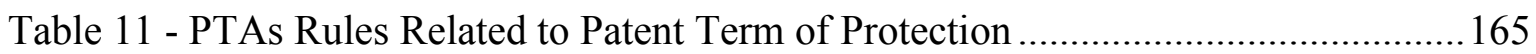

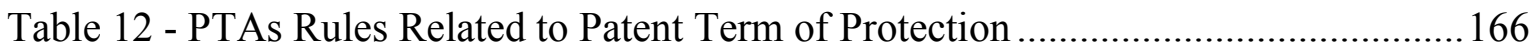

Table 13 - PTAs Rules Related to Patent Term of Protection .............................................167

Table 14 - PTAs Rules on Test Data Submitted to Governmental Agencies ..................... 189

Table 15 - PTAs Rules on Test Data Submitted to Governmental Agencies .....................190

Table 16 - PTAs Rules on Test Data Submitted to Governmental Agencies ......................191

Table 17 - PTAs Rules on Test Data Submitted to Governmental Agencies .....................192

Table 18 - TRIPS-Plus Norms in the Brazilian Intellectual Property Regime ..................209

Table 19 - Horizontal Diffusion of Intellectual Property Norms from the TRIPS Agreement to PTAs ...................................................................................................219

Table 20 - Horizontal Diffusion of Intellectual Property Norms from the TRIPS Agreement

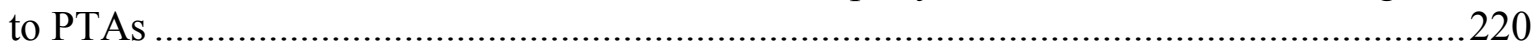

Table 21 - Examples of Horizontal Diffusion of Intellectual Property Norms Between

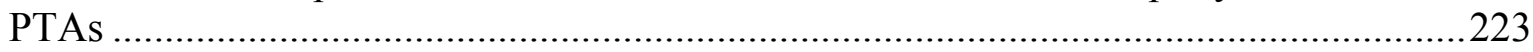

Table 22 - Examples of Vertical Diffusion of Intellectual Property Norms From

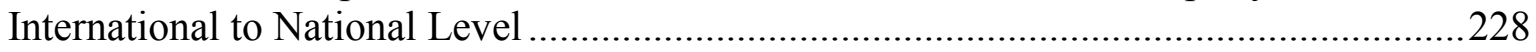




\section{LIST OF FIGURES}

Figure 1 - Parties Involved in PTAs with Patent Provisions - From $1^{\text {st }}$ January 1995 to $1^{\text {st }}$ January 2017

Figure 2 - Cumulative Adoptions of Patent Provisions in PTAs per Year - From $1^{\text {st }}$ January 1995 to $1^{\text {st }}$ January 2017.

Figure 3 - Number of PTAs with Patent Provisions by Country/Trading Block, adopted from $1^{\text {st }}$ January 1995 to $1^{\text {st }}$ January $2017 . .$.

Figure 4 - Number of PTAs per Category of Patent Provision, adopted from $1^{\text {st }}$ January 1995 to $1^{\text {st }}$ January 2017.

Figure 5 - Parties Involved in PTAs with Test Data Provisions, adopted from $1^{\text {st }}$ January 1995 to $1^{\text {st }}$ January 2017

Figure 6 - Cumulative Adoptions of Test Data Provisions in PTAs per Year, from $1^{\text {st }}$ January 1995 to $1^{\text {st }}$ January 2017

Figure 7 - Number of PTAs with Test Data Provisions by Country/Trading Block, adopted from $1^{\text {st }}$ January 1995 to $1^{\text {st }}$ January 2017.

Figure 8 - Number of PTAs per Category of Test Data Provision, adopted from $1^{\text {st }}$ January 1995 to $1^{\text {st }}$ January 2017 


\section{LIST OF ABBREVIATIONS AND ACRONYMS}

\begin{tabular}{|c|c|}
\hline $\mathrm{AB}$ & Appellate Body \\
\hline ABIFINA & $\begin{array}{l}\text { Brazilian Fine Chemicals, Biotechnology and Specialty Industries } \\
\text { Association }\end{array}$ \\
\hline ACTA & Anti-Counterfeiting Trade Agreement \\
\hline ANVISA & Brazilian Health Regulatory Agency \\
\hline ARIPO & African Regional Intellectual Property Organization \\
\hline ARV & Antiretroviral \\
\hline BIRPI & $\begin{array}{l}\text { Bureaux Internationaux Réunis pour la Protection de la Propriété } \\
\text { Intellectuelle }\end{array}$ \\
\hline BPCI & United States Biologics Price Competition and Innovation Act \\
\hline CAFTA & Central American Free Trade Agreement \\
\hline $\mathrm{CBD}$ & Convention on Biological Diversity \\
\hline CDIP & Committee on Development and Intellectual Property \\
\hline CETA & Comprehensive Economic and Trade Agreement \\
\hline CGRFA & Commission on Genetic Resources and Agriculture \\
\hline CGen & Genetic Heritage Management Council \\
\hline CIPIH & Commission on Intellectual Property Rights, Innovation and Public Health \\
\hline CIPR & Commission on Intellectual Property Rights \\
\hline $\mathrm{CMC}$ & Mercosur Common Market Council \\
\hline $\mathrm{COP}$ & Conference of the Parties \\
\hline CRTA & Committee on Regional Trade Agreements \\
\hline CTCN & Climate Technology Centre and Network \\
\hline DARs & Development Agenda Recommendations \\
\hline DESA & UN Department of Economic and Social Affairs \\
\hline DESTA & Design of Trade Agreements Database \\
\hline DNA & Deoxyribonucleic Acid \\
\hline DSB & Dispute Settlement Body \\
\hline DSU & Dispute Settlement Understanding \\
\hline ECA & Economic Complementation Agreement \\
\hline EEA & European Economic Area \\
\hline EFTA & European Free Trade Association \\
\hline EPA & United States Environmental Protection Agency \\
\hline $\mathrm{EPO}$ & European Patent Office \\
\hline EST & Environmentally Sound Technology \\
\hline $\mathrm{EU}$ & European Union \\
\hline FAO & Food and Agriculture Organization \\
\hline FDA & United States Food and Drug Administration \\
\hline FDI & Foreign Direct Investment \\
\hline FD\&C & United States Federal Food, Drug and Cosmetic Act \\
\hline FIFRA & United States Federal Insecticide, Fungicide and Rodenticide Act \\
\hline FOAG & Swiss Federal Office for Agriculture \\
\hline GATT & General Agreement on Tariffs and Trade \\
\hline GATS & General Agreement on Trade in Services \\
\hline IBAMA & Brazilian Institute of Environment and Renewable Natural Resources \\
\hline $\mathrm{ICT}$ & Information and Communication Technologies \\
\hline ICTSD & International Centre for Trade and Sustainable Development \\
\hline
\end{tabular}




\begin{tabular}{|c|c|}
\hline IGC & $\begin{array}{l}\text { Intergovernmental Committee on Intellectual Property and Genetic } \\
\text { Resources Traditional Knowledge and Folklore }\end{array}$ \\
\hline IMF & International Monetary Fund \\
\hline INNs & International Nonproprietary Names \\
\hline INPI & National Institute of Industrial Property \\
\hline IP & Intellectual Property \\
\hline IPR & Intellectual Property Right \\
\hline ITA & Information Technology Agreement \\
\hline ITPGRFA & International Treaty on Plant Genetic Resources and Agriculture \\
\hline ITT & International Technology Transfer \\
\hline JPO & Japan Patent Office \\
\hline LAIA & Latin American Integration Association \\
\hline LDCs & Least-Developed Countries \\
\hline MAPA & Brazilian Ministry of Agriculture, Livestock and Food Supply \\
\hline Mercosur & Southern Common Market \\
\hline $\mathrm{MFN}$ & Most-Favored-Nation \\
\hline MMA & Brazilian Ministry of Environment \\
\hline NAFTA & North American Free Trade Agreement \\
\hline NDE & National Designated Entity \\
\hline NGO & Non-Governmental Organization \\
\hline OECC & Organisation for European Economic Cooperation \\
\hline OECD & Organization for Economic Co-operation and Development \\
\hline PCT & Patent Cooperation Treaty \\
\hline PIC & Prior and Informed Consent \\
\hline PTA & Preferential Trade Agreement \\
\hline RCEP & Regional Comprehensive Economic Partnership \\
\hline $\mathrm{RNC}$ & National Plant Variety Registry \\
\hline RTA & Regional Trade Agreement \\
\hline RTA-IS & Regional Trade Agreement-Information-System \\
\hline $\mathrm{R} \& \mathrm{D}$ & Research and Development \\
\hline SACU & The Southern African Customs Union \\
\hline SCP & WIPO Standing Committee on the Law of Patents \\
\hline SIPO & State Intellectual Property Office of the People's Republic of China \\
\hline SisGen & $\begin{array}{l}\text { National System for the Management of Genetic Heritage and Associated } \\
\text { Traditional Knowledge }\end{array}$ \\
\hline SME & Small and Medium-Sized Enterprise \\
\hline SUS & Brazilian Health System \\
\hline Swissmedic & Swiss Agency for Therapeutic Products \\
\hline SNPC & National Service for Plant Variety Protection \\
\hline SPC & Supplementary Protection Certificate \\
\hline TEC & Technology Executive Committee \\
\hline TFA & Trade Facilitation Agreement \\
\hline TFEU & Treaty on the Function of the European Union \\
\hline TM & Technology Mechanism \\
\hline TNA & Technology Needs Assessment \\
\hline TPA & Swiss Therapeutic Products Act \\
\hline TPP & Trans-Pacific Partnership \\
\hline TRIPS & Agreement on Trade-Related Aspects of Intellectual Property Rights \\
\hline TTIP & Transatlantic Trade and Investment Partnership \\
\hline UPOV & Union for the Protection of New Varieties of Plants \\
\hline
\end{tabular}




$\begin{array}{ll}\text { UN } & \text { United Nations } \\ \text { UNCTAD } & \text { United Nations Conference on Trade and Development } \\ \text { UNDP } & \text { United Nations Development Programme } \\ \text { UNEP } & \text { United Nations Environment Programme } \\ \text { UNESCO } & \text { United Nations Educational, Scientific and Cultural Organization } \\ \text { UNFCCC } & \text { United Nations Framework Convention on Climate Change } \\ \text { UNICITRAL } & \text { United Nations Commission on International Trade Law } \\ \text { UNWTO } & \text { United Nations World Tourism Organization } \\ \text { US } & \text { United States of America } \\ \text { USPTO } & \text { United States Patent and Trademark Office } \\ \text { VCLT } & \text { Vienna Convention on the Law of Treaties } \\ \text { WCO } & \text { World Customs Organization } \\ \text { WESP } & \text { World Economic Situations and Prospects } \\ \text { WHO } & \text { World Health Organization } \\ \text { WIPO } & \text { World Intellectual Property Organization } \\ \text { WTO } & \text { World Trade Organization }\end{array}$




\section{SUMMARY}

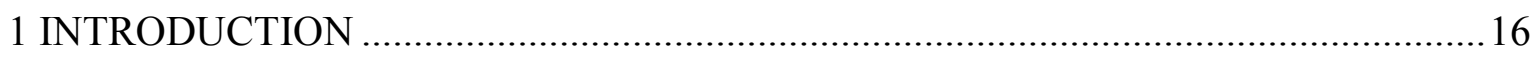

2 THE EXPANSION OF THE INTERNATIONAL INTELLECTUAL PROPERTY SYSTEM THROUGH PREFERENTIAL TRADE AGREEMENTS ................................24

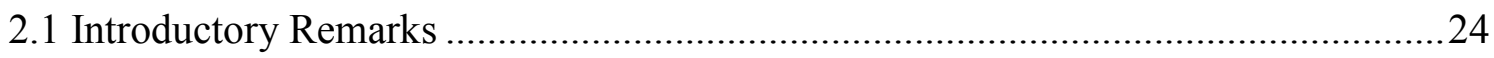

2.2 The Evolving International Dynamics of Intellectual Property Rights Rule-Setting 27

2.3 The WTO Regime and the Legal Effects of PTAs with IP Provisions...................... 37

2.4 Problematic Features of Unbalanced IP Provisions in PTAs ....................................50

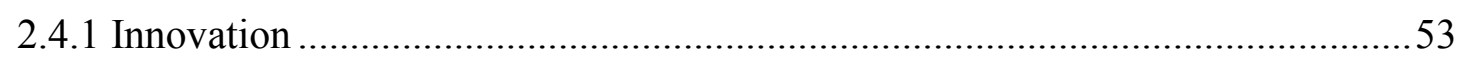

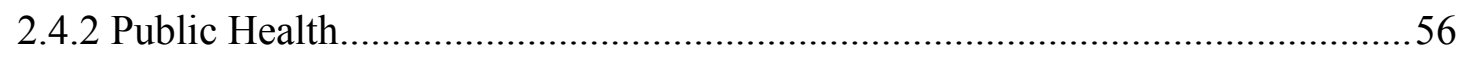

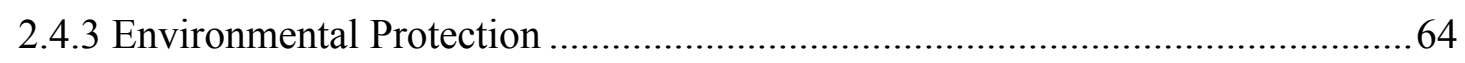

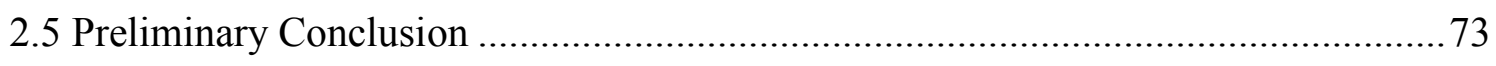

3 THE PATENT AND TEST DATA PROTECTION OBLIGATIONS IN PTAs .............76

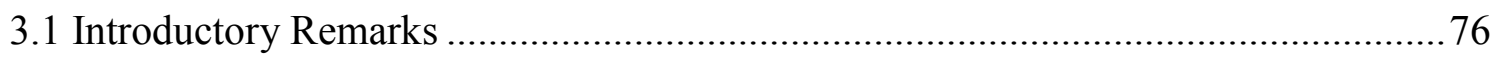

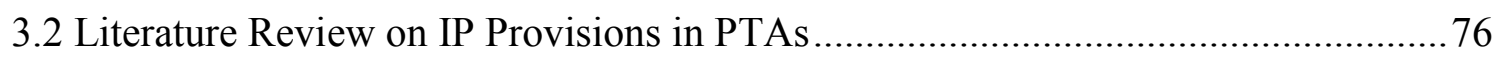

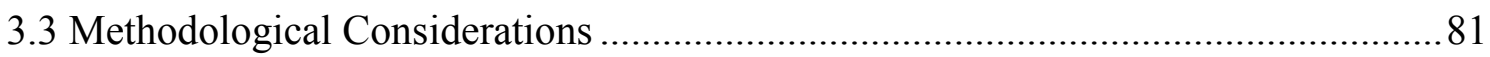

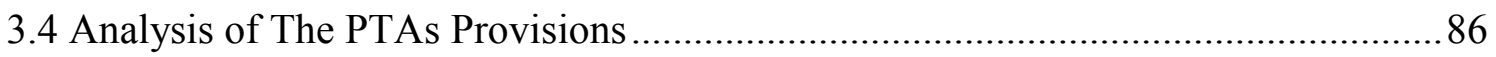

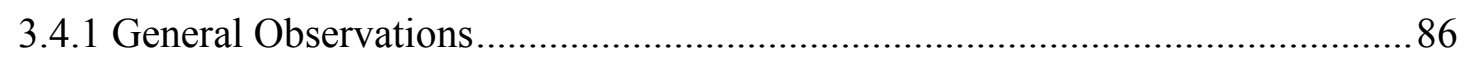

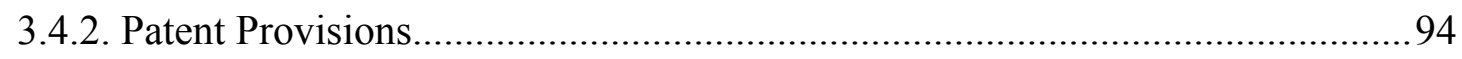

3.4.2.1 Exhaustion of Patent Rights (Parallel Importation) ................................... 94

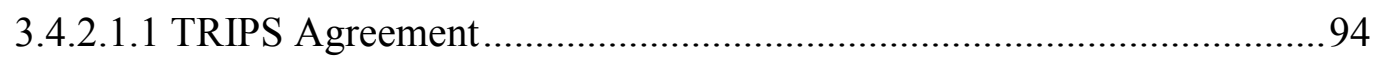

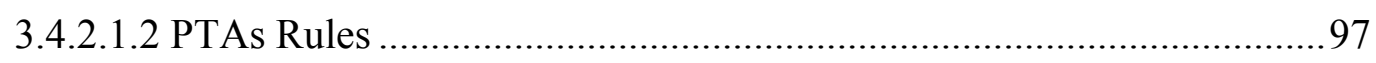

3.4.2.1.3 Brazilian Regime ...................................................................... 98

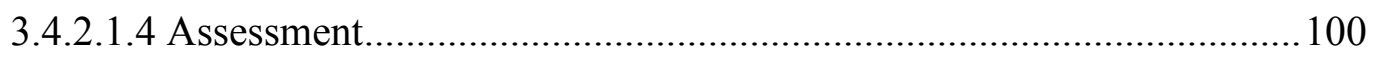

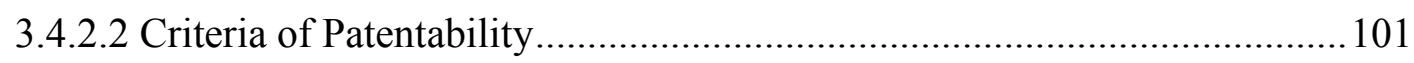

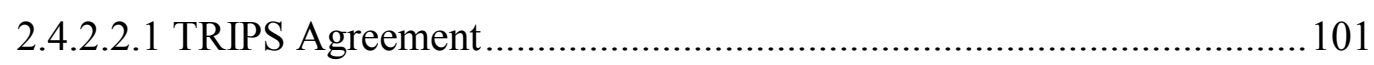

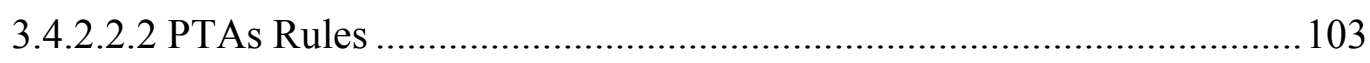

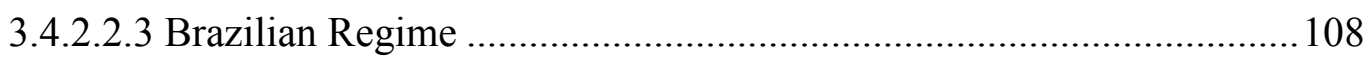

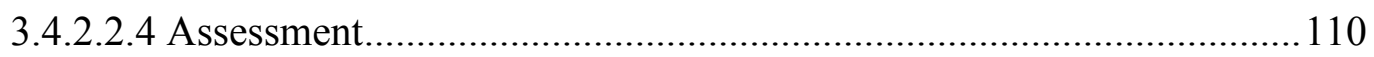

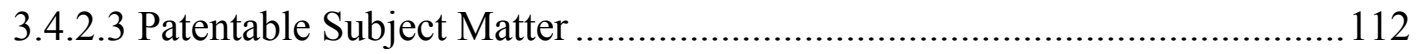

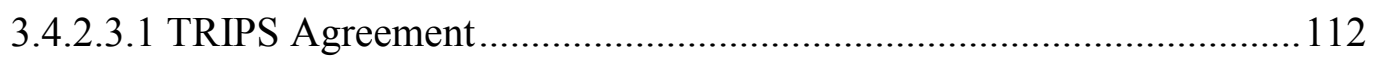

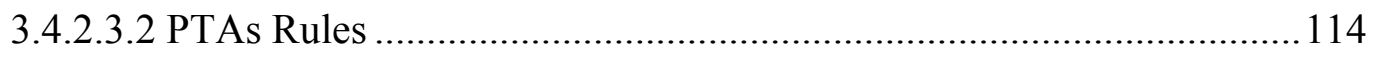

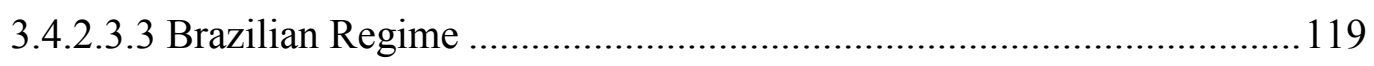

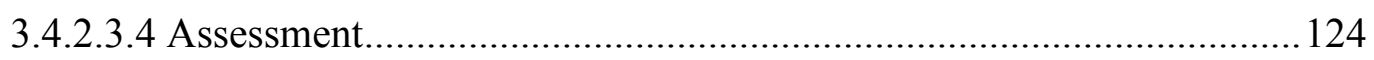


3.4.2.4 Disclosure Requirements of Genetic Resources and Associated Traditional Knowledge

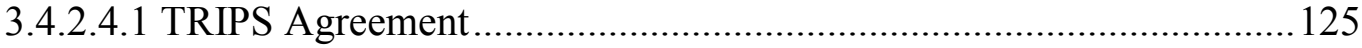

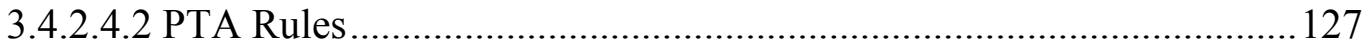

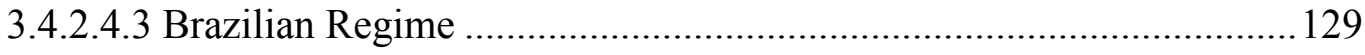

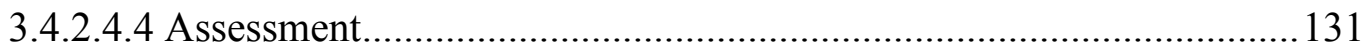

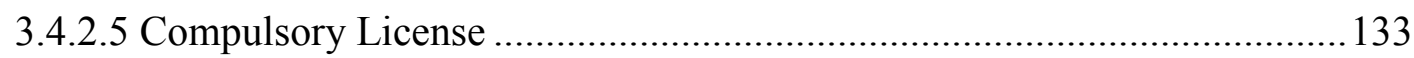

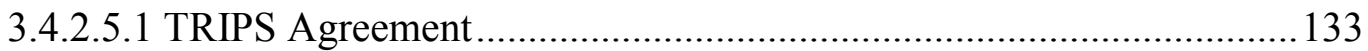

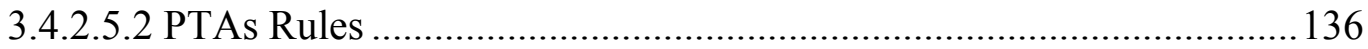

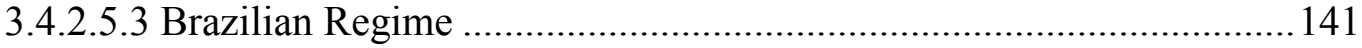

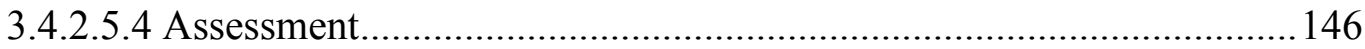

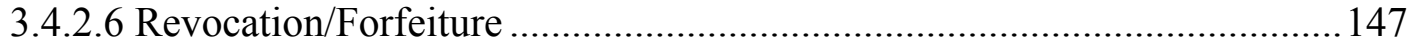

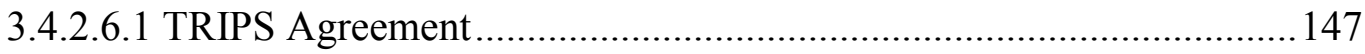

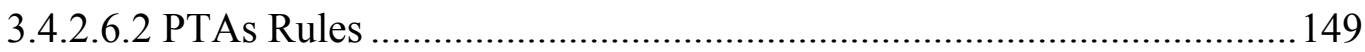

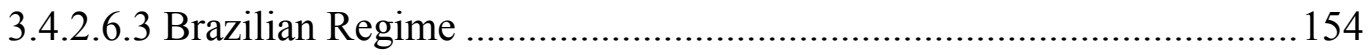

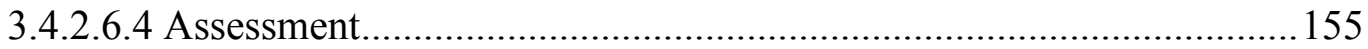

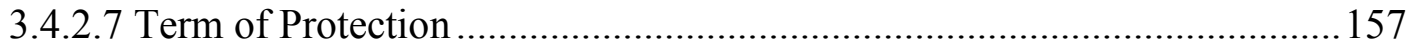

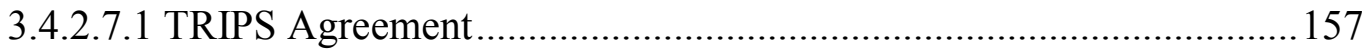

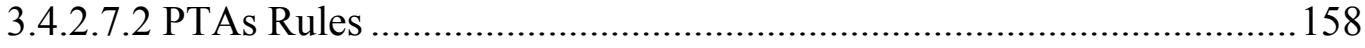

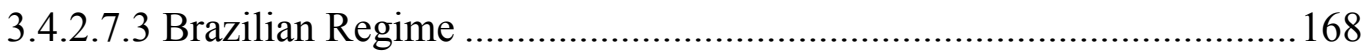

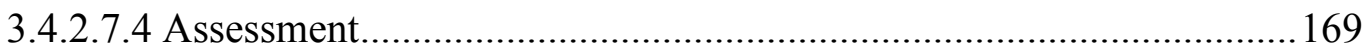

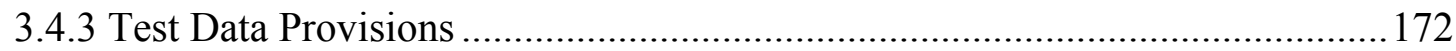

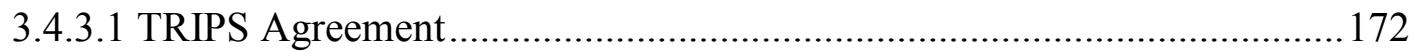

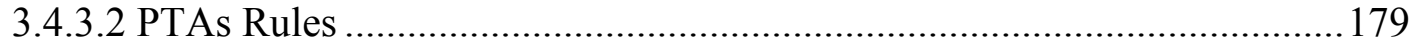

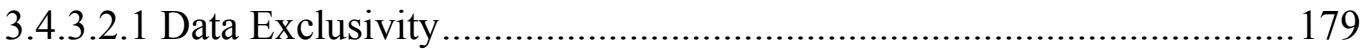

3.4.3.2.2 Market Exclusivity ...................................................................... 182

3.4.3.2.3 Test Data Protection of "New Uses" ................................................. 183

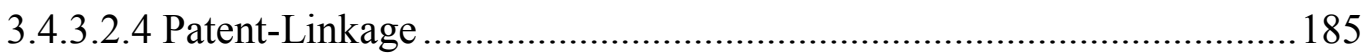

3.4.3.2.5 Notification of the Patent Holder ....................................................... 186

3.4.3.2.6 Test Data Protection for Biologics...................................................... 186

3.4.3.2.7 Data Exclusivity of Medical and Plant Protection Products ............... 187

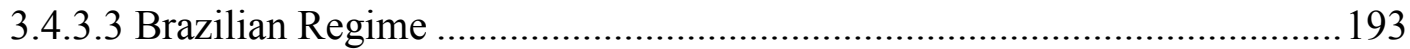

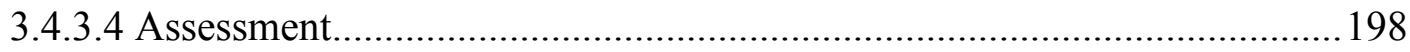

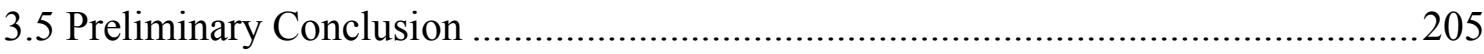

4 DIFFUSION OF INTELLECTUAL PROPERTY NORMS .......................................210

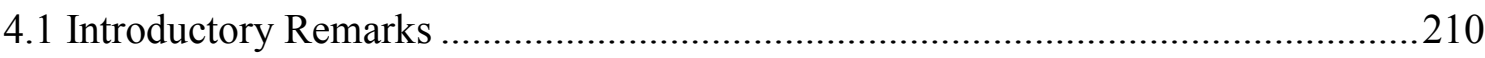

4.2 Diffusion of Intellectual Property Policies and Norms........................................2 211 
4.3 The Diffusion of Intellectual Property Norms Through PTAs ……........................2 217

4.4 Mechanisms for Solving Conflicts of International Law Norms ............................228

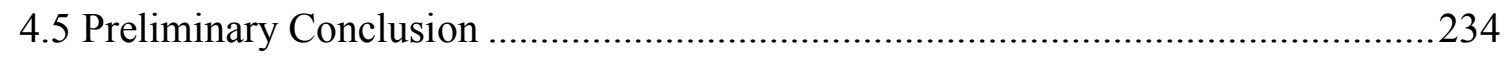

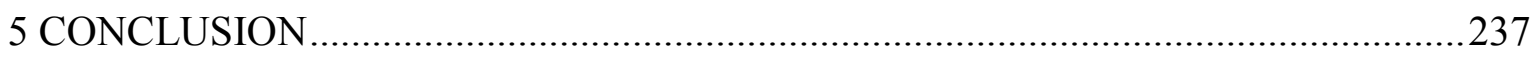

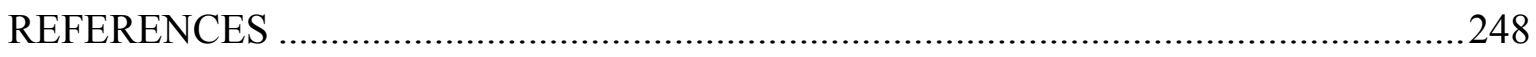

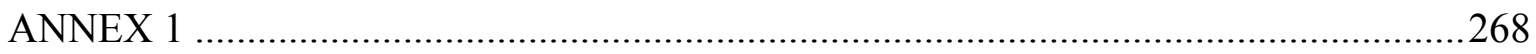




\section{INTRODUCTION}

The world economy is increasingly based on knowledge, information and technology. The advancement in these fields has transformed the national productive capacity, enabling the spread of the production chain all over the world. In order to reduce production costs, national frontiers are overcome through the establishment of regional and global value chains. In the current commercial transactions, a good is no longer designed, manufactured and sold nor a service is provided within a single country. Each of these stages can be executed in a different country and, accordingly, subject to a different national legal regime. By enabling the well-functioning of these production chains throughout the world, the protection and enforcement of intellectual property rights are key components in this process.

In this scenario, the World Trade Organization (WTO) stands out as the main international forum for regulating trade relations, settling trade disputes and monitoring its Member States' trade policy. The WTO is the primary international organization responsible for operating a global system of trade rules based on non-discriminatory principles. Its foundation is part of the historical efforts to establish international institutions aimed at ensuring world peace through multilateral cooperation and economic integration. Since its creation in 1995, the WTO has made great progress in the international trade governance.

However, the WTO is facing one of the most challenging moments in its recent history. The Doha Round of trade negotiations launched in 2001 has not yet been successfully completed. Its stalemate casts doubt on the WTO's capacity to deliver trade rules that reflect the current commercial transactions. Updating the rules demands consensus among all the WTO Members. Under the stewardship of the WTO Director General Roberto Azevêdo, the WTO Members have been able to find consensus in specific topics in the last ministerial conferences, such as the Trade Facilitation Agreement (TFA), the expansion of the Information Technology Agreement (ITA), the elimination of agricultural export subsidies and others measures to support least developed countries. However, this progress remains far below of what was established under the Doha negotiation's mandate. 
Meanwhile, there has been a significant increase in the number of Preferential Trade Agreements (PTAs) adopted in parallel to the WTO's system. Nowadays, a large part of the international world trade happens, in addition to the WTO rules, under the frameworks of PTAs. The new generation of these bilateral and plurilateral treaties not only regulates issues already established under the WTO regime (WTO-In), but also advances (WTOPlus) and creates (WTO-Extra) new rules. They go beyond the mere reduction of tariff barriers in trade in goods and include trade in services and other elements of economic integration, such as investment, regulatory coherence and convergence, labor standards and environmental protection.

In this sense, special attention has been drawn to the acceleration in the conclusion of PTAs with intellectual property (IP) provisions. The WTO 1994 Agreement on TradeRelated Aspects of Intellectual Property Rights (TRIPS Agreement) established minimum standards of intellectual property protection, allowing Member States to adopt higher standards of protection than that accorded in the TRIPS Agreement. Due to this possibility, PTAs have become a major source of international intellectual property regulation. They constitute the main instruments expanding intellectual property rules at the international level. This occurs in a period when intellectual property is increasingly becoming an area of global cooperation and conflict.

The proliferation of intellectual property rules through PTAs is a controversial subject that attracts both criticism and support from different countries. On the one hand, supporters allege that PTAs meet central aspects of the contemporary trade-related aspects of intellectual property rights. On the other hand, opponents argue that their expansion weakens much of the flexibilities provided by the TRIPS Agreements and prevent countries from implementing public policies aimed at their development.

In this context, Brazil is apart from the international economic trend of adopting intellectual property provisions in PTAs. Historically, the country has favored the multilateral sphere as the main forum for establishing any new international intellectual property commitment. It defends that the multilateral level offers the best conditions for developing countries to ensure more balanced results in their areas of interest. The country has refused to adopt any kind of IP provision or to increase the protection levels settled in the TRIPS Agreement in the framework of its PTAs. 
During the 1990s and 2000s, Brazil has made little efforts to build a dense network of PTAs. The few PTAs adopted by Brazil regulate mainly issues already established under the WTO, not advancing nor creating new obligations. In addition, Mercosur, the main Brazilian regional integration project, endures a deep stagnation due to successive political and economic crises in its main State Parties.

For these reasons, part of the literature understands that the superficiality and the limited number of the Brazilian PTAs would be affecting the country's economic growth and its capacity to influence the creation of these new trade rules. The Brazilian refusal to adopt higher levels of commitment would be hindering the performance of its high valueadded exports, frustrating greater attraction of foreign investments; and impeding its insertion in global value chains. As a result, the country would be having fewer resources to implement fundamental public policies for its development.

Therefore, the Brazilian inertia before this new dynamic of establishing new trade rules raises concerns among certain academics and policy-makers. Notwithstanding the historical position of Brazil, the expansion of the international intellectual property regime through PTAs is a fact and probably a long-lasting trend with which the country will be affected sooner or later. The intellectual property rules established under PTAs influence the direction by which the regulation in multilateral forums heads for. The consensus achieved under these frameworks is used as a base for instituting new norms in the multilateral realm.

In the light of the described scenario, the present work raises the following questions: How and to what extend the intellectual property rules that are being established under PTAs differs from the Brazilian intellectual property regime? Does Brazil provide for a higher or lower level of intellectual property protection than the required under PTAs? Which are the advantages or disadvantages related to the adoption of higher standards of intellectual property protection than the required under the TRIPS Agreement? How these intellectual property norms established in PTAs are diffused and interact with other international, regional and national legal spheres?

The interest for this problematic arose during the course "Developing Countries, Globalized Economies and the Challenges of International Regulation", thought by Professors Alberto do Amaral Júnior and Umberto Celli, in the master program at the 
Faculty of Law of the University of São Paulo (USP). The curiosity for the subject was further incited by the studies undertaken by the Center for Global Trade and Investment Studies (CGTI) of the Getulio Vargas Foundation (FGV), under the coordination of Professor Vera Thorstensen. The motivation for the development of the present research resides in understanding how intellectual property provisions in PTAs could be designed to enhance the win-win relation between economic stakeholders and society.

The general objective of the present work is to investigate how and to what extent the intellectual property rules that are being established under PTAs differ from the Brazilian intellectual property regime. In order to achieve this main goal, this work has the following specific objectives: (i) to assess which are the legal issues and the possible effects that pervade the adoption of higher standards of intellectual property protection in PTAs; (ii) to map and analyze the norms on patent and test data protection adopted in PTAs and to compare them with the TRIPS Agreement and the Brazilian intellectual property regime; and (iii) to examine how intellectual property rules are diffused across international, regional and national levels.

These objectives aim not only to present a wider picture and facilitate future research on this subject, but also indicate the intricate challenges arising from the adoption of IP provisions in the PTAs' context. Although there is an extensive literature on TRIPS-Plus, relatively few comprehensive vertical analyzes have been undertaken between the PTAs' patent and test data provisions and the Brazilian intellectual property regime. The present work aims to make a contribution towards closing this gap.

The importance of this research resides in understanding the cross cutting trends in the establishment of new intellectual property rules. The analysis of the patent and test data provisions in PTAs involving parties from all regions and levels of development is key to understand adoption of intellectual property rules in the international level and how the different countries influence each other in this process. The elaboration of a study that analyzes the Brazilian patent and test data regime in the light of these major international trends is fundamental to formulate new legal strategies aimed at fostering innovation and development in the country. Moreover, the regulatory expansion of intellectual property rights through PTAs and its impacts in the multilateral trading system and in the developing countries innovative capacities is one of the greatest challenges to be faced by the WTO in the $21^{\text {st }}$ Century. 
Therefore, this study intends to investigate alternatives to render intellectual property right not a mere instrument of economic monopoly, but a device that promotes the generation of full employment, the increase of population's per capita income, contributing to poverty alleviation and environmental protection. It should be noted that intellectual property is one of the most important drivers of economic development. Its combination with human capital makes it a powerful vector in the current dynamics of the knowledgebased economy. Therefore, intellectual property is increasingly perceived as an important economic asset whose value can be enhanced through proactive and strategic legal design and the implementation of public policies.

When well-managed, intellectual property assets can bring several benefits, such as: generating revenue from the sale of products with IP content and royalties from their licensing, increasing high value-added exports, stimulating research and development industries, supporting teaching institutions, improving the evaluation of companies, attracting joint ventures, and encouraging and maintaining skilled workforce. Intellectual property lies at the heart of the contemporary business strategies. Their protection, however, should not be seen as an end in itself, but as a means to promote innovation and dissemination of knowledge.

As to the basic methodology, this research uses the categorical-deductive method. It departs from general premises on the proliferation of intellectual property rules through PTAs in order to arrive at pertinent and specific conclusions and arguments through logical derivations. The subjects that integrate the universe of this research are the States and customs territories inserted in the international trade dynamics, international organizations, multinational and national companies, non-governmental organizations and the human being as a rights holder.

As to the methodological objectives, the present research is characterized as exploratory, descriptive and explanatory. In the exploratory aspect, the objective is, through the collection of information, to create familiarity and, later, a deeper understanding of the international regulation of the intellectual property rights. This initial exploration will lead to a better understanding about the possibilities of intellectual property promotion, protection and enforcement. In the descriptive aspect, the present research describes the main peculiarities of the patent and test data provisions. It identifies their main characteristics in order to enable their comparison with the TRIPS Agreement 
and the relevant Brazilian legislation. At last, in the explanatory aspect, this research aims to explain the possible differences and similarities between the new rules on patent and test data protection adopted under PTAs and the Brazilian intellectual property regime.

As to the methodological procedures, the research is characterized as bibliographical and documental. The proposal is to develop an extensive bibliographical research, encompassing the perspectives of several national and international authors on the subject. As to documental aspect, this research analyzes the text as primary sources of multilateral intellectual property agreements, PTAs and the several national laws and regulations on intellectual property. These documents are interpreted through data analysis, tables, reports and statistics. This provides an analytical treatment of the information contained in the documents under study.

The present research investigates the patent and test data provisions adopted in the PTAs signed from the entry into force of the TRIPS Agreement, $1^{\text {st }}$ January 1995 , to $1^{\text {st }}$ January 2017. It examines 68 PTAs that together cover 93 countries and separate customs territories possessing full autonomy in the conduction of their external commercial relations. The reason for analyzing patent protection in conjunction with test data protection relies on the fact that TRIPS-Plus provisions are increasingly combining both categories of intellectual property. Therefore, they should be analyzed jointly, even though their object of protection is different.

This study integrates horizontal and vertical methodologies in legal comparison to investigate the complex phenomenon of the TRIPS-Plus provisions in PTAs. It maps and describes the PTAs provisions on patent and test data protection on the basis of carefully constructed classificatory schemes. It describes the similarities and differences between these provisions ant the TRIPS Agreement (horizontal comparison); and between these provisions and the Brazilian patent and test data regime (vertical comparison).

As to the methodological approach, the research is characterized as qualitative and quantitative. In the qualitative aspect, the research takes into consideration the author's subjective interpretation while observing the dynamics between the world and the subject. The quantitative technique is used in the mapping of the patent and test data provisions in PTAs. The research uses calculations and statistics to measure the participation of the patent and test data provisions in the total amount of analyzed PTAs. Hence, the 
information and data collected during the development of the research will be analyzed in categorized way.

The present work proceeds in three main parts. First, it describes the main complexities and problems related to the preferential expansion of intellectual property rules through PTAs. It contextualizes this phenomenon from an historical perspective, demonstrating the international dynamics for the establishment of intellectual property rights in the international realm. It introduces the legal aspects that pervade the interaction between the WTO regime and the intellectual property rules adopted in PTAs. It also indicates the main problematic features of unbalanced IP provisions in PTAs for developing countries.

Second, it undertakes a literature review of studies that investigated the regulation of intellectual property provisions in PTAs. It analyzes the provisions on patent and test data protection accorded under PTAs, from $1^{\text {st }}$ January 1995 to $1^{\text {st }}$ January 2017 . It maps and categorizes these provisions in order to compare them with the TRIPS Agreement and the Brazilian intellectual property regime. This chapter aims to assess how and to what extent the levels of patent and test data protection required under PTAs are higher or lower than the levels provided in Brazil.

Third, it explains how intellectual property policy and norms are diffused across different countries. It shows evidence of diffusion of intellectual property norms on patent and test data protection through PTAs. Moreover, it addresses the issue of the fragmentation of international law, which is aggravated by the proliferation of preferential trade agreements. It delineates possible mechanisms to provide greater coherence between these new intellectual property rules accorded under PTAs, the WTO regime and other international law subsystems.

This dissertation proposes the following hypothesis to be proven in the course of the research: the Brazilian intellectual property regime has a lower level of patent and test data protection than the ones required under the PTAs' TRIPS Plus provisions. Since Brazil refuses to adopt higher levels of intellectual property protection than the level required under the TRIPS Agreement in its PTAs, it is to be expected that the country also only provides for TRIPS-In rules on patent and test data protection in its national legislation. 
In accordance with the above-described parameters, the present work intends to undertake the proposed research and accomplishment the stipulated objectives and the understanding of the object under study. 


\section{THE EXPANSION OF THE INTERNATIONAL INTELLECTUAL PROPERTY SYSTEM THROUGH PREFERENTIAL TRADE AGREEMENTS}

\subsection{Introductory Remarks}

The world has witnessed the increasing proliferation of Preferential Trade Agreements (PTAs) ${ }^{1}$ accorded in parallel to the WTO system in the last decades. In the beginning of the 1990s, there were only around 70 of these agreements in force. By the end of 2010, this number more than quadrupled to nearly 300 (WTO, 2013a, p. 75). By the end of 2016, 643 PTAs had already been notified to the WTO, of which 431 were in force (WTO, 2017a, p. 89). These numbers demonstrate a shift in how international trade is being negotiated and regulated internationally (ELEOTERIO; MESQUITA, 2016, p. 107).

Among the factors that explain the multiplication of such agreements, Baccini and Dür (2011, p. 57) highlight "the stagnation of the process of multilateral trade liberalization, the search for economics of scale, the desire to signal commitments to specific trade and economic policies and the protection of foreign direct investments." In a similar vein, Baldwin (2011) understands this new wave of PTAs as a response to the demands of the $21^{\text {st }}$ Century Regionalism, centered in the "trade-investment-service nexus." The author (BALDWIN, 2011, p. 5) uses this term to describe the growing complexity of the international commerce, characterized by the intertwining of: (i) trade in goods; (ii) international investment in facilities, training, technology and long-term business relationships, and (iii) the use of infrastructure services to coordinate the dispersed production, mainly services such as telecoms, internet, express delivery, air cargo, trade-related finance and customs clearance services.

\footnotetext{
${ }^{1}$ Researchers and policy-makers have often adopted the terms Preferential Trade Agreements (PTAs) and Regional Trade Agreements (RTAs) more or less interchangeably (WTO, 2013, p. 75). According to the WTO (2017b), the term RTA is defined as reciprocal trade agreements between two or more partners, including free trade agreements and customs unions, while the term Preferential Trade Arrangements (note, not agreements) refers to unilateral trade preferences, including no-reciprocal deals (BIRKBECK; BOTWRIGHT, 2015, p. 12). This work adopts, for now on, the term Preferential Trade Agreement (PTA) to refer to these both types of agreements, since the great majority of them are no longer regional in the sense of geographic proximity. The term PTA reflects more appropriately the objective functions of such schemes and the phenomenon that this work intends to depict (MAVROIDIS, 2007, p. 148).
} 


\section{CONCLUSION}

Preferential Trade Agreements have increased in number and importance and cover a significant proportion of the world trade today. They constitute the legal framework that enables the creation of the most advanced regional and global value chains. The presence of intellectual property provisions in PTAs only tends to increase as the world transits from a labor-intensive-economy to a knowledge-based economy. The recent years have been marked by the proliferation of these rules in preferential trade agreements that, through cross-pollination and much of borrowing of national intellectual property norms, influence other States' innovation system.

Historically, the currents and crosscurrents of preferentialism and multilateralism have shaped the adoption of intellectual property rules in the international level. While preferentialism establishes higher standards of protection, multilateralism harmonizes the regulation by consolidating minimum standards. This dialectical cycle of alternation can be perceived in the bilateral IP agreements adopted throughout the nineteenth century that culminated with the adoption of the 1883 Paris Convention and 1886 Bern Convention, as well as the bilateral and regional IP agreements adopted throughout the twentieth century that preceded the adoption of the 1994 TRIPS Agreement. The term "plus" used to characterize the TRIPS as a Bern and Paris-Plus agreement is now being used to refer to the PTAs provisions that exceeds the TRIPS' standards of IP protection (TRIPS-Plus).

In light thereof, the TRIPS Agreement should not be seen as the end point in the development of the international intellectual property regime, nor PTAs be perceived as drastic deviations from the traditional path of regime development. The TRIPS Agreement and these PTAs simply represent, respectively, the systole and diastole movements that characterize the building of the international intellectual property regime. In recent years, the pendulum of the development of intellectual property rules has moved back to preferentialism.

This last wave of preferentialism happens in a context of increasing normalization of the international relations. The multiplication of intellectual property norms in different forums and instruments aggravates the fragmentation of international law. The proliferation of intellectual property rules through PTAs enhances the chances of 
normative conflicts between PTAs themselves, between PTAs and the WTO regime and between PTAs and other international law subsystems. The conflict of international norms, however, shall be seen as natural phenomenon due to the spontaneous, decentralized and non-hierarchical essence of its law-making process. The presumption against conflict, the Vienna Convention on the Law of Treaties and the promotion of a dialogue of sources of international law constitute useful tools to prevent or even solve possible conflicts. This would confer greater coherence, predictability and legal security to the international intellectual property system.

The advancement of intellectual property provisions within the PTAs' framework is, by itself, neither good nor bad. The impact that these norms have depends on the context in which they apply. Their possible beneficial or harmful effects rely upon how they are designed, the country's level of economic and industrial development, the size of the country's domestic market and/or its ability to export, and how and to what extend these rules proceeds in line with the WTO and other multilateral regimes. There is no conclusive evidence that the adoption of stringent intellectual property rights within PTAs leads to a direct and automatic increase in trade, foreign investment and technology transfer. There are other factors - such as macroeconomic stability, efficiency of the judicial system, scientific and technological capabilities, participation in research networks, and other business regulations - that determine the net benefit and impact of a particular intellectual property norm.

Nevertheless, when entering into such commitments, countries should be aware that the adoption of intellectual property provisions in a PTA's framework has significant legal implications regarding not only the WTO system, but also to the national implementation of these obligations. Since the TRIPS Agreement does not provide for a regional integration exception as to the most-favored-nation principle, such as provided in the GATT (Article XXIV) and in the GATS (Article V), any TRIPS-Plus advantage shall be extended to all WTO Members, not only to the PTA's parties. This also has important bargain implications in a PTA's negotiation, since the benefits of an intellectual property concession cannot be offered more than once.

Based on the TRIPS non-discrimination clauses, other WTO Members can even bring complaints before the WTO Dispute Settlement System due to the non-extension of this TRIPS-Plus advantage contained in a PTA. This applies even though this complaining 
WTO Member does not belong to the PTA's contracting parties. Thereby, the TRIPS-Plus concessions made in PTAs indirectly become subject to the WTO Dispute Settlement System. In contrast, the few existing TRIPS-Extra obligations do not need to be extended to other WTO Members, since they do not fall within the TRIPS Agreement's scope. In such cases, PTAs allow for narrow reciprocity based on national treatment.

Furthermore, although TRIPS Article 1:1 allows WTO Members to recognize higher standards of intellectual property protection in international agreements and in their domestic legislation; this shall be undertaken in a manner that it does not contravene the TRIPS Agreement provisions. This non-contravention obligation functions as a coherence mechanism, affecting the States' ability to introduce additional intellectual property protection. As such, any form of more extensive protection needs to be in accordance with the TRIPS Agreement.

Countries should not underestimate the problematic consequences that the implementation of unbalanced TRIPS-Plus provisions might have in their economic, technological, health and environmental policies. By agreeing to more stringent intellectual property rules, countries run the risks of "importing" intellectual property norms that do not reflect their national efficiency trade-off between access to new technologies and incentives for innovation.

The mere strengthening of intellectual property rights does not have a direct positive impact on domestic innovation. It is too simplistic to imply that more intellectual property protection will definitively always lead to more innovation. A balanced intellectual property regime is only one factor among many others - such as institutions, human capital and research, infrastructure, business and market sophistication - that helps to improve a country's innovative environment.

In this context, absorption and imitation are also important approaches to enhance technological catch-up. Certain developed countries, such as the Netherlands, Switzerland and Japan, have already adopted, during a certain period of time, lower standards of intellectual property protection to facilitate the development of their own competitive industrial branches. More recently, this strategy has also been implemented by developing countries, such as China, India and South Korea. The adoption of overprotective IP rules in 
PTAs could harm countries that have not yet achieved a high level of domestic innovation capacity.

The PTAs' pharma-related provisions with higher levels of patent and test data protection may hinder access to affordable health technologies when nationally implemented. Intellectual property rules that provide for longer than normal periods of market exclusivity delay the entry of generic products into the market, postponing competition and maintaining prices high. Besides, the mere adoption of stronger intellectual property rules based on developed countries' law and practice will not necessarily be translated into more investment in research and development of drugs to fight endemic diseases in developing countries, such as malaria, dengue or zika.

Some of these pharma-related provisions are clearly drafted to erode the TRIPS Agreement's room for maneuver that allows WTO Members to design their intellectual property policies in accordance with public health goals. They undermine the long fought and recognized flexibilities enshrined in the 2001 Doha Declaration on the TRIPS Agreement and Public Health. Developing countries should consider that, when committing to these rules within a PTA's framework, their exchange in intellectual property provisions for gains in the agricultural and textile sectors are not automatically converted into higher public or private health expenditures. Further national measures should be put in place to counterbalance the resulting pressure that these norms might have on the national health systems.

More stringent IP rules in PTAs may also restrict countries' capability to meet international and national sustainable development commitments. Higher IP standards might result in higher costs of patented climate change technologies, hinder licensing and affect the affordability of substitute technologies. The rules that form a country's patent regime should be designed to enhance the development, transfer and dissemination of environmentally sound technologies. This constitutes a key strategy to mitigate and adapt to the harmful effects of climate change.

Moreover, PTAs' provisions that require the patentability of plants and animals reproduce and even accelerate the problems already existing in the international level regarding compliance with the obligations on access and benefit sharing. The mere 
availability of patent protection for plants and animals also does not contribute to fight misappropriation of genetic resources worldwide.

On the contrary, PTAs' provisions that require the disclosure of the origin of genetic resources and associated traditional knowledge in patent applications constitute an important mechanism to enhance the mutual-supportiveness between the patent system and the protection of biodiversity. Although they do not solve all the problems related to misappropriation, they do constitute a transparency tool that enables other rights related to the use of biodiversity and traditional knowledge to be enforced. The disclosure provisions demonstrate that intellectual property rules set in PTAs can also advance interests that are primarily linked to developing countries.

The analysis undertaken by this study demonstrated that $79,4 \%$ of the PTAs with patent provisions and $90 \%$ of the PTAs with test data provisions, signed from $1^{\text {st }}$ January 1995 to $1^{\text {st }}$ January 2017, were adopted between developed countries and developing countries/economies in transition. These numbers show that the great majority of PTAs regulating these IP categories have as their normative background a developed-developing country relationship. In this scenario, the PTAs between developed countries or between developing countries are a minority. This study also evidenced the accelerating trend in the conclusion of PTAs with patent and test data protection in the last years. The EFTA, United States and European Union are the most active players in adopting PTAs with patent and test data provisions; while South Korea, Peru and Vietnam are the most active developing countries in this this process.

On patent protection, the identified TRIPS-Plus provisions: (i) prevent parallel importation of patented-products by demanding the institution of national or regional exhaustion regimes of intellectual property rights; (ii) stipulates how the patentability criteria (novelty, inventive, step and industrial application) shall be applied; (iii) demand the grant of patents for "new uses" or methods of using a known product; (iv) restrict potential exclusions from patentability; (v) reduce the circumstances under which compulsory licenses may be issued; (vi) limit the grounds under which a patent may be revoked; (vii) require the disclosure of the origin of genetic resources and associated traditional knowledge in patent applications; (viii) request patent term extension, such as for unreasonable delays in the grating process and for the curtailment of the patent term of protection due to marketing approval. 
On test data protection, the identified TRIPS-Plus provisions: (i) extend the protection to information on safety and efficacy of products other than pharmaceutical and agricultural chemical products, such as biologics; (ii) prevent second applicants from relying on test data submitted to the competent authority by the first applicant (data exclusivity); (iii) prevent the entry into the market of generic products even if the generic manufacturer submits his own test data to the competent authority (market exclusivity); (iv) provide for the protection of test data regarding "new uses" of known compounds; (v) link patent protection to the marketing authorization of pharmaceutical products; and (vi) demand the competent authority to notify the patent holder of any application for marketing a generic pharmaceutical product.

The systematic investigation carried out by this research demonstrated that there is a strong connection between the IP norms accorded under PTAs and the national legislation of the contracting parties. Usually, countries use PTAs as a means to export and import national intellectual property laws and practices. A significant part of the analyzed IP rules pushed through PTAs reflected a national rule on particular subject matter. The term "diffusion" describes this process whereby intellectual property policies and norms are disseminated across different regulatory levels. It occurs through coercion, competition, learning and emulation among countries.

The present study demonstrated that intellectual property rules diffuse in different directions. In a horizontal context, these norms are diffused from the TRIPS Agreement to PTAs as well as from one PTA to another PTA. In a vertical context, these norms are diffused from specific countries' laws and practices to PTAs (bottom-up); and from PTAs to a particular country's laws and practices (top-down).

Developed countries are the main diffusers of intellectual property norms on patent and test data protection. They use their PTAs to disseminate their favored regulatory approaches and their understandings on how the TRIPS flexibilities, exceptions and broad and ambiguous terms should be interpreted and implemented. They play an active role in creating and changing international intellectual property rules and diffusing them into others intellectual property regimes worldwide.

Frequently, a national intellectual property norm from one contracting party is transplanted into the PTA's text to then be internalized into the intellectual property regime 
of the other contracting party. After this norm is widely diffused, it is easier to "multilateralize" it through amendments to the existing multilateral agreements or even through the adoption of a new multilateral agreement. The consensus on a specific intellectual property norm is influenced by its diffusion in the international and national realms.

However, this study calls attention to the fact that, frequently, the parties involved in PTAs with TRIPS-Plus provision simply acknowledge an intellectual property norm or practice already established in their national legislation. In other words, the contracting parties do not always commit to higher standards of IP protection than they already provide internally. By analyzing the implementation of the PTAs patent and test data protection obligations, a significant number of countries merely accorded to provide the same standard of intellectual property protection that they already provided nationally.

Besides, although some countries do commit to adopt higher levels of intellectual property protection than they already provide internally, this does not mean that they will implement them. Some countries never come to internalize their TRIPS-Plus obligations on patent and test data protection accorded within their PTAs. The vertical (top-down) diffusion of these norms does not always occur. This might be explained by the lack of efficient enforceable dispute settlement mechanisms in the great part of PTAs.

At the present moment, Brazil is apart from this preferentialism wave of adopting intellectual property provisions in PTAs. The country cannot influence the development of these new rules, since it rejects to adopt intellectual property commitments in the few and shallow PTAs that it negotiates as a Mercosur State Party or with other LAIA countries. Although it does have offensive interests in the intellectual property field that could be diffused through its PTAs, Brazil rejects to enter into this law-making process that is currently shaping the international intellectual property system. A possible way for Brazil to counterbalance regulatory trends that are being set against its interests and resist the pressure from developed countries in the multilateral forums is to build its own coalition through its PTAs' network.

The analysis undertaken by this study demonstrated that the Brazilian intellectual property regime does not radically differ from the TRIPS-Plus provisions on patent and test data protection that are being adopted under PTAs. Brazil already has intellectual 
property laws that exceed the level of protection required under the TRIPS Agreement. The country promptly incorporated the TRIPS Agreement's obligations and even renounced the transition periods to developing countries. The differences between the Brazilian intellectual property regime and the analyzed TRIPS-Plus obligations vary in accordance to each specific category of provision.

On the one hand, it is remarkable how Brazil extensively used the policy space provided under the TRIPS Agreement to build its intellectual property regime. The country was able to benefit from various exceptions and constructive ambiguities provided by the text of the TRIPS Agreement. The country adopts a strict interpretation of the patentability criteria and excludes methods of treatment, plants and animals from patentability.

Brazil has even already used the flexibility of the TRIPS Article 31 to issue a compulsory license of the antiretroviral drug Efavirenz. The measure enabled the national health system to expand the access to treatment for the people with HIV/AIDS in the country. The Brazilian regime provides for other grounds - such as abuse of patent rights, non-working of the patent, public interest - for the granting of a compulsory license than the grounds exemplified by TRIPS Agreement. Differently from what is being negotiated under the PTAs, the Brazilian Industrial Property Law also provides for a several grounds upon which a patent may be revoked.

On test data protection, the national legislation permits the reliance on the information submitted to ANVISA for the marketing approval of pharmaceutical products for human use. The Brazilian intellectual property regime does not provide for patentlinkage nor the obligation of the competent regulatory authority to inform the patent holder of any marketing approval request for a product that still under patent protection. It also does not provide for the adjustment of the patent term of protection due to delays in a product's marketing approval. The marketing approval in Brazil is granted regardless of the product is under patent protection or not.

On the other hand, Brazil has stricter rules than the ones accorded under the TRIPS Agreement or even than the TRIPS-Plus provisions that are being adopted under PTAs. The country prohibits parallel importation of patented products, since it adopts, as a general rule, the national exhaustion regime of intellectual property rights. This doctrine blocks, for example, the parallel importation of cheaper medicines into the country. The 
doctrine of international exhaustion, in contrast, is usually recommended to developing countries that want to reduce the weight of the medicines' costs in their national health budgets.

Moreover, Brazil allows for the grant of patents for "new uses" of known compounds, provided that they meet the patentability requirements. If this analysis is not diligently undertaken, the INPI runs the risk of patenting the same product for much longer than a single period. That is to say, patents for "new uses" can have an "ever greening" effect, unduly postponing competition in the national market.

The Brazilian regime ensures a minimum term of ten years of patent protection for cases in which INPI, by its own fault, delays the granting of the patent in over ten years. The problem of this kind of rule is that it imposes a burden on the society due to negligence or error of the public administration. It would be easier and more effective to improve INPI's work in a way that makes it acts expeditiously than to postpone the access to cheaper technological goods to the Brazilian society. Therefore, it is crucial to provide INPI the necessary infrastructure and staff to examine all the patent applications in a timely manner.

Given its immense biodiversity, Brazil also requires the disclosure of the origin of national genetic resources and associated traditional knowledge in patent applications. However, these disclosure requirements only apply to patent applications based on Brazilian genetic resources and associated traditional knowledge. This obligation does not bind patent applications based on third countries genetic resources and associated traditional knowledge. Hence, the Brazilian approach does little in the global efforts to implement transparency tools that help to combat the misappropriation of genetic resources. The implementation of this obligation in a way that it does not differentiate between national and foreign genetic resources could enhance the transparency of patent applications not only for Brazil, but also for other countries.

On test data protection, the Brazilian regime grants data exclusivity to information concerning the safety and efficacy of plant protection and veterinary products. This obligation prevents the competent regulatory authorities from disclosing the test data submitted to them (secrecy) and from using this information in favor of subsequent applicants (non-reliance). The period of data exclusivity lasts 5 years, for old entities, or 10 
years for new entities, whether chemical or biological. However, it is worth mentioning that as long as competitors submit their own test data, even regarding veterinary and plant protection products, they can always be granted marketing approval. There is no "market exclusivity" for test data under the Brazilian regime.

The analysis undertaken by this research allows us to partially reject the initial hypothesis proposed by this dissertation. The results demonstrated that Brazilian intellectual property regime does not always have a lower level of patent and test data protection than the ones required under the TRIPS-Plus provisions in PTAs. As evidenced, in certain aspects, the Brazilian intellectual property regime on patent and test data protection has even higher standards the ones found in the analyzed PTAs.

In the future, Brazil should use intellectual property commitments in its PTAs to limit the adoption of particularly harmful unilateral strategies. This can be undertaken by safeguarding the TRIPS flexibilities and by reinforcing the letter and spirit of the 2001 Doha Declaration on the TRIPS Agreement and Public Health. The country should use to the fullest extend the room for maneuver left by the TRIPS Agreement to design a procompetitive PTA. Brazil could design a model of IP chapter that addresses the issues that it perceives as problematic under the TRIPS Agreement. The country could, thus, advance its understandings on how the TRIPS provisions should be better interpreted and implemented.

This process demands a better organization of the Brazilian internal IP interests. This is a key component to ensure that future international IP commitments faithfully reflect the country's demands. This includes consultations not only with Brazilian IP right holders, but also with Brazilian IP users and consumers. The different stakeholders should be equally able to express their respective interests in this process. Brazil should not diffuse IP standards that only serve the interests of few economically powerful right holders. The interests of few should not harm the welfare of the country as a whole. This exercise of internal consensus building before the adoption of IP provisions facilitates the point in which the PTA is subject to democratic control and put on the table of parliamentarians to be ratified.

Brazil does not need to abandon the multilateral level of intellectual property norm setting, but it can combine it with others bilateral, plurilateral and regional spheres. The 
country should promote an open regionalism, aimed at improving its innovative environment in a non-discriminatory manner. Therefore, Brazil should ensure that possible IP provisions in its future PTAs are sufficiently flexible to take into account the socioeconomic situations and needs of its contracting parties. This can be built on through the permission of countries to adopt exceptions and limitations necessary for pursuit of legit public policy goals. These IP provisions should also be designed to respect other international obligations, particularly those relating to the protection of the environment, biological diversity, food security and public health. 


\section{REFERENCES}

ABBOTT, Frederick. Trade Costs and Shadow Benefits: EU Economic Partnership Agreements as Models for Progressive Development of International IP Law. In: DREXL, Josef; RUSE-KHAN, Henning; NADDE-PHLIX, Souheir (Ed.). EU Bilateral Trade Agreements and Intellectual Property: for Better or Worse? Berlin: Springer, 2014.

Innovation and Technology Transfer to Address Climate Change: Lessons from the Global Debate on Intellectual Property and Public Health. ICTSD's Programme on IPRs and Sustainable Development, Geneva, n. 24, p. 1-38, Jun. 2009.

. Intellectual Property Rights in the World Trade. In: GUZMAN, Andrew; SYKES, Alan (Ed.). Research Handbook in International Economic Law. Cheltenham: Edward Elgar, 2007.

. The Cycle of Action and Reaction: Developments and Trends in Intellectual Property Health. In: ROFFE, Pedro; TANSEY, Geoff; VIVAS-EUGUI, David (Ed.). Negotiating Health: Intellectual Property and Access to Medicines. London: Earthscan, 2006.

. Intellectual Property Provisions of Bilateral and Regional Trade Agreements in Light of U.S Federal Law. UNCTAD - ICTSD Project on IPRS and Sustainable Development, Geneva, n. 12, p. 1 - 28, Feb. 2006.

. The WTO Medicines Decision: World Pharmaceutical Trade and the Protection of Public Health. The American Journal of International Law, Washington, v. 99, n. 2, p. $317-358$, Apr. 2005.

Toward a New Era of Objective Assessment in the Field of TRIPS and Variable Geometry for the Preservation of Multilateralism. Journal of International Economic Law, v. 8, n. 1, p. 77-100, Jan. 2005.

. The Doha Declaration on the TRIPS Agreement and Public Health and the Contradictory Trend in Bilateral and Regional Free Trade Agreements. Quaker United Nations Office, Geneva, Ocassional Paper 14, Apr. 2004.

ABBOTT, Frederick; COTTIER, Thomas; GURRY, Francis. International Intellectual Property in an Integrated World Economy. New York: Aspen Publishers, 2007.

ACHARYA, Amitav. Norm Subsidiarity and Regional Orders: Sovereignty, Regionalism, and Rule-Making in the Third World. International Studies Quarterly, v. 55, n. 1, p. 95123, Mar. 2011.

. How Ideas Spread: Whose Norms Matter? Norm Localization and Institutional

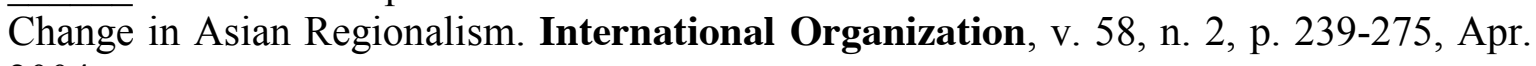
2004. 
ACOSTA, Luis et al. Patent Term Extensions and Adjustments: Australia, Canada, European Union, France, Germany, Israel, Japan, South Korea, United Kingdom. Washington: The Law Library of the Congress, 2016. Available at: $<$ https://www.loc.gov/>. Accessed on: 18 Oct. 2017.

AFONSO, Larissa. Exclusões e Exceções ao Direito de Patentes. 2013. $371 \mathrm{f}$. Dissertação (Mestrado em Direito) - Universidade de São Paulo, São Paulo, 2013.

AGÊNCIA NACIONAL DE VIGILÂNCIA SANITÁRIA - ANVISA. Regularização de Produtos Agrotóxicos. Available at: $<$ http://portal.anvisa.gov.br/registros-eautorizacoes/agrotoxicos/produtos/registro>. Accessed on: 26 Sep. 2017.

AGUIAR JÚNIOR, Ruy. Direito de Patente e Transgenia. Revista da Associação Brasileira da Propriedade Intelectual, v. 120, p. 54-67, Sep./Oct. 2012.

AHLERT, Ivan; DESIDERIO, Teixeira. A Patenteabilidade dos Novos Usos de Substâncias Conhecidas. Revista da Associação Brasileira da Propriedade Intelectual, v. 100, p. 23-31, May/Jun. 2009.

ALEMAN, Marco. Impact of TRIPS-Plus Obligations in Economic Partnership- and Free Trade Agreements on International IP Law. In: DREXL, Josef; RUSE-KHAN, Henning; NADDE-PHLIX, Souheir (Ed.). EU Bilateral Trade Agreements and Intellectual Property: for Better or Worse? Heidelberg, Springer, 2014.

ALIKHAN, Shahid; MASHELKAR, Raghunath. Intellectual Property and Competitive Strategies in the $21^{\text {st }}$ Century. The Hague: Kluwer Law International, 2004.

ALMEIDA, Renata; VASCONCELLOS, Alexandre. Sobre a Extensão das Patentes Farmacêuticas no Brasil: Existe Remédio à Luz dos Poderes do Estado? Cadernos de Prospecção, v. 7, n. 4, p. 504-515, Oct./Dec. 2014.

ALMEIDA, Liliane. A Validade do Prazo Fixado pelo INPI para a Patente Mailbox. Revista da Associação Brasileira da Propriedade Intelectual, v. 130, p. 24-41, May./Jun. 2014.

ALOUI, Omar. Intellectual Property. In: HUFBAUER, Gary; BRUNEL, Claire (Ed.). Capitalizing on the Morocco-US Free Trade Agreement: a Road Map for Success. Washington: Peterson Institute, 2009.

AMARAL JÚNIOR, Alberto do. Curso de Direito Internacional Público. 4 ed. São Paulo: Atlas, 2013.

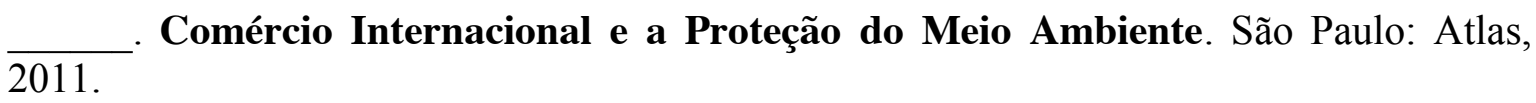

. O Diálogo das Fontes: Fragmentação e Coerência no Direito Internacional Contemporâneo. Anuário Brasileiro de Direito Internacional, v. 2, p. 11-33, Jul. 2008. 
ARBIX, Daniel do Amaral. Tratados TRIPS Plus e o Sistema Multilateral do Comércio. 2009. 203 f. Dissertação (Mestrado em Direito) - Universidade de São Paulo, São Paulo, 2009.

BACCINI, Leonardo; DÜR, Andreas. The New Regionalism and Policy Interdependence. British Journal of Political Science, Cambridge, v. 42, n. 1, p. 57-79, Jun. 2011.

BACCINI, Leonardo; DÜR, Andreas; HAFTEL, Yoram. Imitation and Innovation in International Governance. In: DÜR, Andreas; ELSIG, Manfred (Ed.). Trade Cooperation: The Purpose, Design and Effects of Preferential Trade Agreements. Cambridge: Cambridge University Press, 2015.

BALDWIN, Richard. $21^{\text {st }}$ Century Regionalism: Filling the Gap Between the $21^{\text {st }}$ Century Trade and $20^{\text {th }}$ Century Trade Rules. World Trade Organization - Economic Research and Statistic Division, Geneva, Staff Working Paper ERSD-2011-08, p. 1-18, May 2011.

BARBOSA, Denis. Uma Introdução à Propriedade Intelectual. 2 ed. Rio de Janeiro: Lumen Juris, 2003.

. Tratado da Propriedade Intelectual. Rio de Janeiro: Lumen Juris, 2010.

A Inexplicável Política Pública por Trás do Parágrafo Único do Art. 40 da Lei de Propriedade Industrial. Revista da Escola de Magistratura Regional Federal, v. 19, n. 1, p. 127-186, Nov./Apr. 2014.

BARBOSA, Pedro. A Proteção dos Dados de Testes Sigilosos Submetidos à Regulação Estatal. Revista da Escola da Magistratura Federal 2a Região, v. 12, n. 1, p. 234-285, Aug. 2009.

BARTELT, Sandra. Compulsory Licenses Pursuant to TRIPS Article 31 in the Light of the Doha Declaration on the TRIPS Agreement and Public Health. The Journal of World Intellectual Property, v. 6, n. 2, p. 283-310, Mar. 2003.

BASSO, Maristela; RODRIGUES JÚNIOR, Edson. Intellectual Property in Brazil. New York: Wolters Kluwer, 2010.

BIRKBECK, Carolyn; BOTWRIGHT, Kimberley. The Future of the Global Trade and Investment Architecture: Pursuing Sustainable Development in the Global Economy Overview of Issues, Challenges and Debates. E15initiative. Geneva: International Centre for Trade and Sustainable Development (ICTSD) and World Economic Forum, 2015. Available at: $<$ http://e15initiative.org/publications/the-future-of-the-global-trade-andinvestment-architecture/> Accessed on: 16 Jun. 2016.

BIRKBECK, Carolyn; MARCHANT, Ron. Implementation of the Technical Assistance of the WIPO Development Agenda. The Journal of Intellectual Property, v. 14, n. 2, p. 103-132, Mar. 2011.

BOFF, Salete Oro. Acesso aos Conhecimentos Tradicionais: Repartição de Benefícios pelo Novo Marco Regulatório. Revista Direito Ambiental e Sociedade, v. 5, n. 2, p. 110-127, 2015. 
. Patentes na Biotecnologia e Desenvolvimento. In: BARRAL, Welber; PIMENTEL, Luiz Otávio (Org.). Propriedade Intelectual e Desenvolvimento. Florianópolis: Fundação Boiteux, 2007.

BONADIO, Enrico. Parallel Imports in a Global Market: Should a Generalized International Exhaustion be the Next Step? European Intellectual Property Review, v. 33, p. 153-161, Feb. 2011.

BRAGA, Carlos; FINK, Carsten; SEPULVEDA, Claudia. Intellectual Property Rights and Economic Development. World Bank Discussion Paper, n. 412, p. 1 - 57, Mar. 2000.

BRANSTETTER, Lee. TPP and the Conflict over Drugs: incentives for innovation versus access to medicines. In: SCHOTT; Jeffrey, CIMINO-ISAACS, Cathleen. Assessing the Trans-Pacific Partnership. Volume 2: innovations in trading rules. Washington: Peterson Institute for International Economics, 2016.

BRUNDTLAND, Harlem. Report of the World Commission on Environment and Development: Our Common Future. New York: United Nations, 1987.

CALLAGHAN, Dayle; MENDOCA, Sarah. Gulf Co-operation Council Countries: the emerging IP landscape. Thomas Reuters Practical Law, 17 Sep. 2014. Available at: $<$ https://www.rouse.com/magazine/articles/news-and-articles/gulf-co-operation-councilcountries-the-emerging-ip-landscape/>. Accessed on: 22 Nov. 2017.

CARVAlHO, Nuno. The TRIPS Regime of Patent and Test Data. 4 ed. Kluwer: Alphen aan den Rijn, 2014.

The TRIPS Regime of Patent Rights. 2 ed. Kluwer: The Hague, 2005.

CELLI JÚNIOR, Umberto; ELEOTERIO, Belisa. O Brasil, o Mercosul e os Acordos Preferenciais de Comércio: alternativas e perspectivas. In: IGLESIAS, Enrique; DAMIANI, Gerson; GARCÉ, Adolfo; ZIBETTI, Fabíola (Org.). Os Desafios da América Latina no Século XXI. São Paulo: EDUSP, 2015.

CELLI JÚNIOR, Umberto; SALLES, Marcus; TUSSIE, Diana; PEIXOTO, Juliana. Mercosur in South-South Agreements: in the Middle of Two Models of Regionalism. Geneva: UNCTAD, 2010. Available at: <https://vi.unctad.org/resources-mainmenu64/digital-library?view=search>. Accessed on: 30 Nov. 2017.

CELLI JÚNIOR, Umberto. A OMC e a Fragmentação das Regras do Sistema de Comércio Internacional nos Acordos Preferenciais de Comércio. In: BAPTISTA, Luiz Olavo; RAMINA, Larissa; FRIEDRICH, Tatyana (Coord.). Direito Internacional Contemporâneo. Curitiba: Juruá, 2014.

COMMISSION ON INTELLECTUAL PROPERTY RIGHTS. Integrating Intellectual Property and Development Policy. London: CIPR, 2002.

CORIAT, Benjamin; ORSENIGO, Luigi. IPRs, Public Health and the Pharmaceutical Industry: Issues in the Post-2005 TRIPS Agenda. In: CIMOLI, Mario; DOSI, Giovanni; 
MASKUS, Keith; OKEDIJI, Ruth; REICHMAN, Jerome; STIGLITZ, Joseph (Ed.). Intellectual Property Rights: Legal and Economic Challenges for Development. Oxford: Oxford University Press, 2014.

CORREA, Carlos. Patent Rights. In: CORREA, Carlos; YUSUF, Abdulqawi (Ed.). Intellectual Property and International Trade: the TRIPS Agreement. 3ed. Alphen aan den Rijn: Wolters Kluwer, 2016.

. TRIPS and TRIPS-Plus Protection and Impacts in Latin America. In: GERVAIS, Daniel. Intellectual Property, Trade and Development: strategies to optimize economic development in a TRIPS-Plus era. Oxford: Oxford University Press, 2007.

Bilateral Investment Agreements: agents of new global standards for the protection of intellectual property rights? Transnational Dispute Management, v. 1, n. 4, p. 1- 31, Aug. 2004.

COSTA, Cíntia; PARANHOS, Julia; VASCONCELLOS, Alexandre. Brasil, Índia e China: o Marco Legal da Biodiversidade e a Proteção Patentária no Âmbito do Sistema Farmacêutico de Inovação. XV Congresso Latino-Iberoamericana de Gestão de Tecnologia. 2013, Porto. Proceedings... Porto: ALTEC, 2013. Available at: $<$ http://www.altec2013.org/programme_pdf/655.pdf >. Accessed on: 17 Oct. 2017.

COTTIER, Thomas; SIEBER-GASSER, Charlotte; WERMELINGER, Gabriela. The Dialectical Relationship of Preferential and Multilateral Trade Agreements. In: DÜR, Andreas; ELSIG, Manfred (Ed.). Trade Cooperation: the Purpose, Design and Effects of Preferential Trade Agreement. Cambridge: Cambridge University Press, 2015.

COTTIER, Thomas. Working Together Towards TRIPS. In: WATAL, Jayashree; TAUBMAN, Antony (Ed.). The Making of the TRIPS Agreement: Personal Insights from the Uruguay Round Negotiations. Geneva: WTO, 2015.

CURTIS, John. Trade and Innovation: Policy Options for a New Innovation Landscape. Geneva: International Centre for Trade and Sustainable Development and World Economic Forum, 2016.

D'ALMEIDA, Cristina et. al. New Antiretroviral Treatments and Post-2005 TRIPS Constraints: First Moves Towards IP Flexibilization in Developing Countries. In: CORIAT, Benjamin (Ed.). The Political Economy of HIV/AIDS in Developing Countries: TRIPS, Public Health Systems and Free Access. Cheltenham: Edward Elgar, 2008.

DE CONINCK, Heleen; SAGAR, Ambuj. Technology in the 2015 Paris Climate Agreement and Beyond. Geneva: ICTSD, 2015.

DECHEZLEPRÊTRE, Antoine. Fast-Tracking Green Patent Applications: An Empirical Analysis. Geneva: ICTSD, 2013.

DEL NERO, Patrícia. Biotecnologia: Análise Crítica do Marco Jurídico Regulatório. São Paulo: Editora Revista dos Tribunais, 2008. 
DERZKO, Natalie. Using Intellectual Property Law and Regulatory Processes to Foster the Innovation and Diffusion of Environmental Technologies. In: MENELL, Peter; TRAN, Sarah (Ed.). Intellectual Property, Innovation and the Environment. Cheltenham: Edward Elgar, 2014.

DESIGN OF TRADE AGREEMENTS DATABASE - DESTA. Project Description. Available at: < https://www.designoftradeagreements.org/project-description/>. Accessed on: 11 Jul. 2017.

DESSEMONTET, François. Protection of Undisclosed Information. CORREA, Carlos; YUSUF, Abdulqawi (Ed.). Intellectual Property and International Trade: the TRIPS Agreement. 3ed. Alphen aan den Rijn: Wolters Kluwer, 2016.

DINCA, Razvan. The "Bermuda Triangle" of Pharmaceutical Law: Is Data Protection a Lost Ship? Journal of World Intellectual Property, v. 8, n. 4, p. 517-563, Jul. 2005.

DINWOODIE, Graeme B. The Architecture of the International Intellectual Property System. Chicago-Kent Law Review, v. 77, p. 993-1014, Jan. 2002.

DRAHOS, Peter. BITS and BIPS: Bilateralism in Intellectual Property. The Journal of World Intellectual Property, v. 4, n. 6, p. 791-808, Nov. 2001.

. The Universality of Intellectual Property Rights: Origins and Development. In: WORLD INTELLECTUAL PROPERTY ORGANIZATION (Org.). Intellectual Property and Human Rights. Geneva: WIPO, 1999.

DREXL, Josef. The Concept of Trade-Relatedness of Intellectual Property Rights in Times of Post-TRIPS Bilateralism. In: In: ULLRICH; Hans; HILTY, Reto; LAMPING, Matthias; DREXL, Josef (Ed.). TRIPS plus 20: from Trade Rules to Market Principles. Heidelberg: Springer, 2016.

DÜR, Andreas; BACCINI, Leonardo; ELSIG, Manfred. The Design of International Trade Agreements: Introducing a New Dataset. The Review of International Organizations, v. 9, n. 3, p. 353-375, Sep. 2014.

ELEOTERIO, Belisa; MESQUITA, Alebe. The Twenty-First Century Regionalism: Brazil and Mercosur in the New International Scenario. In: ADINOLFI, Giovanna; BAETENS, Freya; CAIDO, José; LUPONE, Angela; MICARA, Anna (Ed.). International Economic Law: Contemporary Issues. Cham: Springer, 2016.

ELKINS, Zachary; SIMMONS, Beth. On Waves, Clusters and Diffusion. The Annals of the American Academy of Political and Social Science. The Annals of the American Academy of Political and Social Science, v. 598, n. 1, p. 33-51, Mar. 2005.

EL-SAID, Mohammed. TRIPS-Plus, Public Health and Performance-Based Rewards Schemes Options and Supplements for Policy Formation in Developing and Least Developed Countries. American University International Law Review, v. 31, n. 3, p. 373-444, Sep. 2016. 
ELSING, Manfred; SURBECK, Jenny. Intellectual Property Rights and Preferential Trade Agreements: Data, Concepts and Research Avenues. NCCR Trade Working Paper, Working-Paper No. 2016/2, p. 1-17, Apr. 2016.

EUROPEAN FREE TRADE ASSOCIATION - EFTA. The Agreement on the European Economic Area. Available at: $<\mathrm{http}: / / \mathrm{www} . e f t a . i n t /$ eea/eea-agreement $>$. Accessed on: 26 Jul. 2017.

\section{EUROPEAN COMISSION - EC. Supplementary Protection Certificates for Pharmaceutical and Plant Protection Products. Available at: $<$ https://ec.europa.eu/growth/industry/intellectual-property/patents/supplementary- protection-certificates_en $>$. Accessed on: 9 Aug. 2017a.}

Procedure to apply for authorization of a PPP. Available at: <

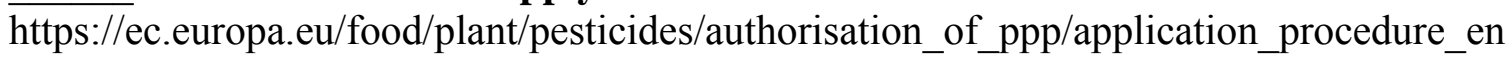
>. Accessed on: 30 Sep. 2017 b.

FARRAN, Sue; RAUTENBACH, Christa. Introduction. In: FARRAN, Sue; GALLEN, James; HENDRY, Jennifer; RAUTENBACH, Christa (Ed.). The Diffusion of Law: the Movement of Laws and Norms Around the World. New York: Routledge, 2015.

FEKETE, Elisabeth. Importações Paralelas: A Implementação do Princípio da Exaustão de Direitos no Mercosul Diante do Contexto de Globalização. Anais do XVII Seminário Nacional da Propriedade Intelectual, Porto Alegre, 1997. Proceedings... Porto Alegre: Associação Brasileira de Propriedade Intelectual, 1997.

FINK, Carsten. Intellectual Property. In: CHAUFFOUR, Jean-Pierre; MAUR, JeanChristophe (Ed.). Preferential Trade Agreement Policies for Development: a handbook. Washington: World Bank, 2011.

Regime Shifting in the International Intellectual Property System. Perspective on Politics, v. 7, n. 01, p. 39-44, Mar. 2009.

FINK, Carsten; MASKUS, Keith. Why We Study Intellectual Property Rights and What We Have Learned. In: FINK, Carsten; MASKUS, Keith (Ed.). Intellectual Property and Development: Lessons from Recent Economic Research. Washington: World Bank, 2005.

FINK, Carsten; REICHENMILLER, Patrick. Tightening TRIPS: The Intellectual Property of Recent US Free Trade Agreements. World Bank Trade Note, n. 20, p. 1-11, Feb. 2005.

FIRTH, Alison. Reception of EU Trade Mark Law in New Zealand. In: BJÖRKDAHL, Annika; CHABAN, Natalia; LESLIE, John; MASSELOT, Annick (Ed.). Importing EU Norms: Conceptual Framework and Empirical Findings. Heidelberg: Springer, 2015.

FLYNN, Sean et al. The US Proposal for an Intellectual Property Chapter in the TransPacific Partnership Agreement. American University Law Review, v. 28, n. 1, p. 105-202, 2013. 
FRANKEL, Susy. The Intellectual Property Chapter in the TPP. In: LIM, C. L; ELMS, Deborah; LOW, Patrick (Ed.). The Trans-Pacific Partnership: a quest for a twenty-firstcentury trade agreement. Cambridge: Cambridge University Press, 2012.

GERVAIS, Daniel. The TRIPS Agreement: Drafting History and Analysis. 2 ed. London: Sweet \& Maxwell, 2003.

GILARDI, Fabrizio. Transnational Diffusion: Norms, Ideas and Policies. In: CARLSNAES, Walter; RISSE, Thomas; SIMMONS, Beth (Ed.). Handbook of International Relations. 2 ed. London: Sage Publications, 2012.

GLICK, David; FRIEDLAND, Zoe. How Often do States Study Each Other? Evidence of Policy Knowledge Diffusion. American Politics Research, v. 42, n. 6, p. 956-985, Mar. 2014.

GOLLIN, Michael. Using Intellectual Property to Improve Environmental Protection. In: MENELL, Peter; TRAN, Sarah (Ed.). Intellectual Property, Innovation and the Environment. Cheltenham: Edward Elgar, 2014.

GRUBB, Philip; THOMSEN, Peter. Patents for Chemicals, Pharmaceuticals, and Biotechnology: Fundamentals of Global Law, Practice and Strategy. 5 ed. Oxford: Oxford University Press, 2010.

GUISE, Mônica. Comércio Internacional, Patentes e Saúde Pública. Curitiba: Juruá, 2007.

HALL, Bronwyn; HELMERS, Christian. The Role of Patent Protection in (Clean/Green) Technology Transfer. Santa Clara Computer and High Technology Law Journal, v. 26, n. 4, p. $487-532$, Aug. 2010.

HELFER, Laurence R. Regime Shifting in the International Intellectual Property System. Perspective on Politics, v. 7, n. 01, p. 39-44, Mar. 2009.

. Toward a Human Rights Framework for Intellectual Property. UC Davis Law $\overline{\text { Review}}$, Davis, v. 40, n. 3, p. 971-1020, Mar. 2007.

- Regime Shifting: the TRIPS Agreement and New Dynamics of Intellectual Property Lawmaking. Yale Journal of International Law, v. 29, n. 1, p. 1-84, Winter 2004.

Intellectual Property Rights in Plant Varieties: International Legal Regimes and Policy Options for National Governments. Rome: FAO, 2004.

HENNINGER, Thomas. Disclosure Requirements in Patent Law and Related Measures: a Comparative Overview of Existing National and Regional Legislation on IP and Biodiversity. In: WERTH, Alexander; REYES-KNOCHE, Susanne (Ed.). Triggering the Synergies Between Intellectual Property Rights and Biodiversity. Eschborn: GTZ, 2010. 
HESTERMEYER, Holger. Human Rights and the WTO: the Case of Patents and Access to Medicines. Oxford: Oxford University Press, 2007.

HILTY, Reto. The Proportionality Principle in the TRIPS Agreement. In: ULLRICH; Hans; HILTY, Reto; LAMPING, Matthias; DREXL, Josef (Ed.). TRIPS plus 20: from Trade Rules to Market Principles. Heidelberg: Springer, 2016.

INTERNATIONAL LAW COMMISSION - ILC. Fragmentation of International Law: Difficulties Arising from the Diversification and Expansion of International Law. Geneva: United Nations, 2006.

. Draft Articles on Most-Favoured-Nations Clauses. Yearbook of the International Law Commission, v. 2, p. 16-73, 1978.

. Home. Available at: <http://legal.un.org/ilc/>. Accessed on: 12 Nov. 2017.

INTERNATIONAL UNION FOR THE PROTECTION OF NEW PLANT VARIEITES. About UPOV. Available at: $<$ http://www.upov.int/portal/index.html.en>. Accessed on: 2 Apr. 2017.

INSTITUTO DANNEMANN SIEMSEN DE ESTUDOS DE PROPRIEDADE INTELECTUAL - IDS. Comentários à Lei de Propriedade Industrial. Rio de Janeiro: Renovar, 2005.

INSTITUTO NACIONAL DA PROPRIEDADE INDUSTRIAL - INPI. Marco Legal da Biodiversidasde Cria Novas Exigências para o Exame de Patentes. Available at: $<$ http://www.inpi.gov.br/noticias/marco-legal-da-biodiversidade-cria-novas-exigenciaspara-o-exame-de-patentes $>$. Accessed on: 10 Oct. 2017.

JANSEN, Nils. Comparative Law and Comparative Knowledge. In: REIMANN, Mathias; ZIMMERMANN, Reinhard. The Oxford Handbook of Comparative Law. Oxford: Oxford University Press, 2006.

JEFFERSON, David. Development, Farmers' Right and the Ley Monsanto: the Struggle over the Ratification of UPOV 91 in Chile. IDEA - The Intellectual Property Law Review, v. 55, n. 1, p. 31-78, 2014.

JENKS, Wilfred. The Conflict of Law-Making Treaties. British Book of International Law, v. 30, p. 401-453, 1953.

KAMERI-MBOTE, Patricia; OTIENO-ODEK, James. Genetic Use Restriction Technologies and Sustainable Development in Eastern and Southern Africa. In: MÉLENDEZ-ORTIZ, Ricardo; ROFFE, Pedro (Ed.). Intellectual Property and Sustainable Development: Developing Agendas in a Changing World. Cheltenham: Edward Elgar, 2009.

KANG, Peter; STONE, Clarck. IP, Trade and U.S - Singapore Relations: Significant Intellectual Property Provisions of the 2003 U.S - Singapore Free Trade Agreement. The Journal of World Intellectual Property, v. 6, n. 5, p. 721-731, Sep. 2003. 
KONGOLO, Tshimanga. Morocco's Patent System and its International Connection. IDEA: The Journal of Law and Technology, v. 42, n.1, p. 181-204, p. 2002.

KUANPOTH, Jakkrit. TRIPS-Plus Rules under Free Trade Agreements: An Asian Perspective. In: HEATH, Christopher; SANDERS, Anselm (Ed.). Intellectual Property and Free Trade Agreements. Oxford: Hart, 2007.

KUNG, Angela; MACHADO, José. Comentários à Lei N. 10.603/02. Proteção às Informações Não Divulgadas. Revista da Associação Brasileira de Propriedade Intelectual, v. 64, p. 63-66, May./Jun. 2003.

LEITE, Márcio. O Patenteamento de Invenções de Segundo Uso no Brasil. 2011. 152 f. Dissertação (Mestrado em Direito) - Universidade de São Paulo, São Paulo, 2011.

LI, Yahong. Intellectual Property and Public Health: Two Sides of the Same Coin. Asian Journal of WTO \& International Health Law and Policy, v. 6, n. 2, p. 389 - 428, Sep. 2011.

LIMA, Newton et al. A Revisão da Lei de Patentes: Inovação em Prol da Competitividade Nacional. Brasília: Edições Câmara, 2013.

LINDSTROM, Beatrice. Scaling Back TRIPS-Plus: Analysis of Intellectual Property Provisions in Trade Agreements and Implications for Asia and the Pacific. New York University Journal of International Law and Politics, v. 42, n. 3, p. 917 - 980, Spring 2010 .

LLANOS, María Victoria. Reflections on the Moroccan Patent System. Queen Mary Journal of Intellectual Property, London, 2015. Available at: $<$ https://qmjip.wordpress.com/2015/07/17/reflections-on-the-moroccan-patent-system/>. Accessed on: 18 Nov. 2017.

LOUREIRO, Luiz Guilherme. A Lei da Propriedade Industrial: comentada. São Paulo: Lejus, 1999.

LOWENFELD, Andreas. International Economic Law. 2 ed. Oxford: Oxford University Press, 2011.

MALBON, Justin; LAWSON, Charles; DAVISON, Mark. The WTO Agreement on Trade-Related Aspects of Intellectual Property Rights: a Commentary. Cheltenham: Edward Elgar, 2014.

MANNERS, Ian. Normative Power Europe: A Contradiction in Terms? Journal of Common Market Studies, v. 40, n. 2, p. 235-258, Jun. 2002.

MARCEU, Gabrielle; REIMAN, Cornelis. When and how is a regional trade agreement compatible with the WTO? Legal Issues of Economic Integration, v. 28, n. 3, p. 297-336, 2001.

MASKUS, Keith; OKEDIJI, Ruth. Legal and Economic Perspectives on International Technology Transfer in Environmentally Sound Technologies. In: CIMOLI, Mario; DOSI, 
Giovanni; MASKUS, Keith; OKEDIJI, Ruth (Ed.). Intellectual Property Rights: Legal and Economic Challenges for Development. Oxford: Oxford University Press, 2014.

MASKUS, Keith. Implications of Regional and Multilateral Agreements for Intellectual Property. The World Economy, v. 20, n. 5, p. 681-694, Aug. 1997.

MAVROIDIS, Petros. Trade in Goods. Oxford: Oxford University Press, 2007.

MAX PLANCK INSTITUTE. Declaration on Patent Protection: Regulatory Sovereignty under TRIPS. Munich: Max Planck Institute for Innovation and Competition, 2014. Available at: $<$ https://www.mpg.de/8133454/Patent-Declaration1.pdf $>$. Accessed on 2 Jun. 2017.

MAY, Christopher. The World Intellectual Property Organization and the Development Agenda. Global Governance, v. 13, n. 2, p. 161 - 170, Apr./Jun. 2007.

MEITINGER, Ingo. Implementation of Test Data Protection According to Article 39.3. TRIPS: The Search for a Fair Interpretation of the Term "Unfair Commercial Use." The Journal of World Intellectual Property, v. 8, n. 2, p. 123-139, Mar. 2005.

MELÉNDEZ-ORTIZ, Ricardo. Foreword. In: BARTON, John. Intellectual Property and Access to Clean Energy Technologies in Developing Countries. Geneva: ICTSD, 2007.

MERCADO COMUM DEL SUR - MERCOSUR. Protocol on Harmonization of Rules on Intellectual Property in Mercosur, in the Matter of Trademarks, Indications of Origin, and Names of Origin. Available at: $<$ http://www.mercosur.int/innovaportal/v/2648/12/innova.front/tratados-protocolos-eacordos>. Accessed on: 30 Nov. 2017.

MERCURIO, Bryan. TRIPS-Plus Provisions in FTAs: Recent Trend. In: BARTELS, Lorand; ORTINO, Federico (Ed.). Regional Trade Agreements and the WTO System. Oxford: Oxford University Press, 2006.

MESIDOR, Marie Dagmar. Intellectual Property Rights in Competition Law: Compulsory License Issues in Developing Countries. Revista da Associação Brasileira de Propriedade Intelectual, v. 128, 17-30, Jan./Fev. 2014.

MEY, Brenda. Unfettered Consumer Access to Affordable Therapies in the Post-TRIPS Era: a Dead-End Journey for Patients? Kenya and India Case Studies. Journal of World Intellectual Property, v. 13, n. 3, p. 403 - 473, Jan. 2010.

MICHAEL, Gabriel. International Coercion and the Diffusion of Regulatory Data Protection. Journal of World Intellectual Property, v. 19, n. 2, p. 2-127, Mar. 2016.

MINISTÉRIO DA AGRICULTURA, PECUÁRIA E ABASTECIMENTO - MAPA. Registro de Produtos Veterinários de Natureza Farmacêutica. Available at: $<$ http://www.agricultura.gov.br/acesso-a-informacao/acoes-e-programas/cartas-deservico/defesa-agropecuaria-produtos-de-uso-veterinario/registro-de-produtos-veterinariosde-natureza-farmaceutica>. Accessed on: 27 Sep. 2017. 
MINISTÉRIO DA ÍNDÚSTRIA, COMÉRCIO EXTERIOR E SERVIÇOS - MDIC. Acordos dos quais o Brasil é Parte. Available at: <http://www.mdic.gov.br/comercioexterior/negociacoes-internacionais/796-negociacoes-internacionais-2>. Accessed on: 14 Dec. 2017.

$\begin{array}{lccc}\text { MINISTÉRIO DAS RELAÇÕES } & \text { EXTERIORES - MRE. The Latin American } \\ \text { Integration } & \text { Association } & \text { (ALADI-LAIA). } & \text { Available }\end{array}$ $<$ http://www.itamaraty.gov.br/en/politica-externa/integracao-regional/5975-aladi-en>. Accessed on: 30 Nov. 2017.

MITCHELL, Andrew; VOON, Tania. Patents and Public Health in the WTO, FTAs and Beyond: Tension and Conflict in International Law. Journal of World Trade, v. 43, n. 3, p. 571-601, Jun. 2015.

MONT'ALVERNE, Tarin. A Convenção sobre a Biodiversidade e o Acordo sobre os Aspectos dos Direitos de Propriedade Intelectual Relacionados ao Comércio: Possível Conciliação? XIX Encontro Nacional do CONPEDI, 2010, Fortaleza. Proceedings... Florianópolis: Fundação $\quad$ Boiteux, 2010. Available at: $<$ http://150.162.138.7/documents/download/537; jsessionid=76318633730745622734A0A FD559325D>. Accessed on: 13 Jun. 2017.

MOMIROV, Aleksandar; FOURIE, Andria. Vertical Comparative Law Methods: Tools for Conceptualising the International Rule of Law. Erasmus Law Review, v. 2, n. 3, p. 291 309, Nov. 2009.

MOON, Surie. Meaningful Technology Transfer to the LDCs: a Proposal for a Monitoring Mechanism for TRIPS Article 66.2. ICTSD Policy Brief, Geneva, n. 9, p 1 - 18, Apr. 2001.

MUSUNGU, Sisule. The TRIPS Agreement and Public Health. In: CORREA, Carlos; YUSUF, Abdulqawi (Ed.). Intellectual Property and International Trade: the TRIPS Agreement. New York: Wolters Kluwer, 2008.

MUSUNGU, Sisule; OH, Cecilia. The Use of Flexibilities in TRIPS by Developing Countries: can they promote access to medicines? Geneva: South Center, 2006.

OKEDIJI, Ruth. Back to Bilateralism? Pendulum Swings in International Intellectual Property Protection. University of Ottawa Law \& Technology Journal, v. 1, n. 1, p. 125 $-147,2004$.

ORGANISATION FOR ECONOMIC CO-OPERATION AND DEVELOPMENT. OECD History. Available at: $<$ https://www.oecd.org/about/history/>. Accessed on: 2 Apr. 2017 a.

Intellectual Property (IP) Statistics and Analysis. Available at: $\overline{<\mathrm{http}: / / w w w . o e c d . o r g / i n n o v a t i o n / i n t e l l e c t u a l-p r o p e r t y-s t a t i s t i c s-a n d-a n a l y s i s . h t m>. ~}$ Accessed on: 2 Apr. $2017 b$.

ÖRÜCÜ, A. Esin. Methodology of Comparative Law. In: SMITS, Jan (Ed.). Elgar Encyclopedia of Comparative Law. 2 ed. Cheltenham: Edward Elgar, 2012. 
PAUWELYN, Joost. Conflict of Norms in Public International Law: How WTO Law Relates to other Rules of International Law. Cambridge: Cambridge University Press, 2003.

PAUWELYN, Joost; ALSCHNER, Wolfgang. The network of relations between PTAs and double PTAs. In: DÜR, Andreas; ELSIG, Manfred (Ed.). Trade Cooperation: the Purpose, Design and Effects of Preferential Trade Agreement. Cambridge: Cambridge University Press, 2015.

POLIDO, Fabrício; DOS ANJOS, Lucas. Acordos de Investimento e a Proteção de Direito de Propriedade Intelectual: Relação Natural, ou Casamento de Conveniência? Reflexões sobre experiências do Mercosul e do Nafta. Revista de la Secretaría del Tribunal Permanente de Revisión, v. 8, p. 258-282, Aug. 2016.

PRICE, David. The U.S - Bahrain Free Trade Agreement and Intellectual Property Protection. The Journal of World Intellectual Property, v. 7, n. 6, p. 829-850, Nov. 2004.

PRIFTI, Viola. Plant Variety Protection: Options under the TRIPS Agreement. In: CORREA, Carlos; YUSUF, Abdulqawi (Ed.). Intellectual Property and International Trade: the TRIPS Agreement. 3 ed. Alphen ann den Rijn: Wolters Kluwer, 2016.

PUGATCH, Meir. Intellectual Property, Data Exclusivity, Innovation and Market Access. In: ROFFE, Pedro; TANSEY, Geoff; VIVAS-EUGUI, David (Ed.). Negotiating Health: Intellectual Property and Access to Medicines. London: Earthscan, 2006.

RAMOS, André; GUTERRES, Thiago. Lei de Propriedade Industrial Comentada: Lei 9.279, de 14 de Maio de 1996. Salvador: JusPodivm, 2016.

RAUSTIALA, Kal. Density and Conflict in International Intellectual Property Law. UC Davis Law Review, v. 40, n. 3, p. 1021-1038, Mar. 2007.

RAYOL, Alice. Tendências de exame dos pedidos de Patente na Área da Biotecnologia. Revista da Associação Brasileira de Propriedade Intelectual, n. 63, p. 49-56, Mar./Apr. 2003.

REICH, Arie. The WTO as Law-Harmonizing Institution. University of Pennsylvania Journal of International Economic Law, v. 25, n. 1, p. 321-382, Spring 2004.

REICHMAN, Jerome; RAI; Arti; NEWELL, Richard; WIENER, Jonathan. Intellectual Property and Alternatives: Strategies for Green Innovation. In: CIMOLI, Mario; DOSI, Giovanni; MASKUS, Keith; OKEDIJI, Ruth (Ed.). Intellectual Property Rights: Legal and Economic Challenges for Development. Oxford: Oxford University Press, 2014.

REICHMAN, Jerome. Compulsory Licensing of Patented Pharmaceutical Inventions: Evaluating the Options. Journal of Law, Medicine and Ethics, v. 37, n. 2, p. 247-263, Jun. 2009.

REIMANN, Mathias. Beyond National Systems: A Comparative Law for the International Age. Tulane Law Review, v. 75, n. 4, p. 1103-1120, Mar. 2001. 
RODRIGUES, Daniele. As Flexibilidades do Acordo TRIPS na Nova Dinâmica Comercial Internacional. In: AMARAL JÚNIOR, Alberto; CELLI JÚNIOR, Umberto (Org.). A OMC: desafios e perspectivas. São Paulo: Aduaneiras, 2014.

ROFFE, Pedro; SANTA CRUZ, Maximiliano. Intellectual Property Rights and Sustainable Development: a Survey of Major Issues. Santiago: ECLAC, 2007.

ROFFE, Pedro. Bilateral Agreements and a TRIPS-Plus World: the Chile-USA Free Trade Agreement. Ottawa: Quaker International, 2004.

RORIZ, João Henrique; TASQUETTO, Lucas. Comércio e Regras sobre Propriedade Intelectual nos Acordos Preferenciais de Comércio. In: OLIVEIRA, Ivan; BADIN, Michelle (Org.). Tendências Regulatórias nos Acordos Preferenciais de Comércio no Século XXI: os Casos de Estados Unidos, União Europeia, China e Índia. Brasília: IPEA, 2013.

ROS, Viorel. Protection of Inventions in the Pharmaceutical Sector Through Supplementary Protection Certificate. Lex et Scientia International Journal, n. 22, v.1, p. 7-30, Jun. 2015.

ROSENBERG, Barbara. Propriedade Intelectual. In: THORSTENSEN, Vera; JANK, Marcos (Coord.). O Brasil e os Grandes Temas do Comércio Internacional. São Paulo: Aduaneiras, 2005.

RUSE-KHAN, Henning Grosse. The Protection of Intellectual Property in International Law. Oxford: Oxford University Press, 2016.

. The Role of TRIPS in a Fragmented IP World. International Review of Intellectual Property and Competition Law, v. 43, n. 8, p. 881-884, Dec. 2012.

SACCARO JÚNIOR, Nilo. O Uso dos Recursos Genéticos para o Desenvolvimento Sustentável Brasileiro. Boletim Regional, Urbano e Ambiental, v. 7, p. 35-43, Jan./Jun. 2013.

SANDERS, Anselm. The Development Agenda for Intellectual Property: Rational Humane Policy or Modern-Day Communism? In: HEATH, Christopher; SANDERS, Anselm (Ed.). Intellectual Property and Free Trade Agreements. Oxford: Hart, 2007.

SARNOFF, Joshua. The Patent System and Climate Change. Virginia Journal of Law \& Technology, v. 16, n. 2, p. 301-360, Mar. 2011.

SCARCIGLIA, Roberto. Comparative Methodology and Pluralism in Legal Comparison in a Global Age. Beijing Law Review, v. 6, n. 1, p. 42-48, Mar. 2015.

SCHAFFER, Gregory; SELL, Susan. Transnational Legal Ordering and Access to Medicines. In: OKEDIJI, Ruth; BAGLEY, Margo (Ed.). Patent Law in Global Perspective. Oxford: Oxford University Press, 2014. 
SCHÄLI, Mathias. Freihandelsabkommen Schweiz - China: Zeitenwende beim Schutz des geistigen Eigenturms? In: HERREN, Jürg; MÜNCH, Peter; HOCHREUTENER, Inge (Org.). IP-Herausforderungen in China: Hintergrund, Entwicklungen, Lösungsansätze. Bern: Growth Publisher, 2016.

SCHOTT, Jeffrey. Free Trade Agreements: Boon or Bane of the World Trading System. In: SCHOTT, Jeffrey (Ed.). Free Trade Agreements: US Strategies and Priorities. Washington: Institute for International Economics, 2004.

SEARLE, Nicola; BRASSELL, Martin. Economic Approaches to Intellectual Property. Oxford: Oxford University Press, 2016.

SEGGER, Marie-Claire. Advancing the Paris Agreement on Climate Change for Sustainable Development. Cambridge Journal of International and Comparative Law, v. 5, n. 2, p. 202-237, Jan. 2016.

SELL, Susan. TRIPS Was Never Enough: Vertical Forum Shifting, FTAs, ACTA, and TPP. Journal of Intellectual Property Law, v. 18, n. 2, p. 447-478, Mar. 2011.

. TRIPS-Plus Free Trade Agreements and Access to Medicines. Liverpool Law Review, v. 28, n. 1, p. 41-75, Apr. 2007.

SEUBA, Xavier. Intellectual Property in Preferential Trade Agreements: What Treaties, What Content? The Journal of World Intellectual Property, v. 16, n. 5-6, p. 240-261, Dec. 2013.

Trade, Public Health, and the 2030 Agenda for Sustainable Development. Geneva: ICTSD, 2017.

SHADLEN, Kenneth; GUENNIF, Samira; GUZMÁN, Alenka; LALITHA, N. Globalization, Intellectual Property Rights and Pharmaceuticals: meeting the challenges to addressing health gaps in the new international environment. In: SHADLEN, Kenneth; GUENNIF, Samira; GUZMÁN, Alenka; LALITHA, N. (Ed.). Intellectual Property, Pharmaceuticals and Public Health: Access to Drugs in Developing Countries. Cheltenham: Edward Elgar, 2011.

SHIPAN, Charles; VOLDEN, Craig. Policy Diffusion: Seven Lessons for Scholars and Practitioners. Public Administration Review, v. 72, n. 6, p. 788-796, Nov./Dec. 2012.

The Mechanisms of Policy Diffusion. American Journal of Political Science, v. $\overline{52, \text { n. } 4}$, p. $840-857$, Oct. 2008.

SICHEL, Ricardo. Licença Compulsória de Patentes. Revista da Escola da Magistratura Regional Federal da 2a Região, v. 13, n.1, p. 151-164, May 2010.

SILVA, Ana Paula; VALLINI, Juliana. A Proteção à Informação Não Divulgada na Área de Saúde: Uma Abordagem Internacional. In: CARVALHO, Patrícia (Coord). Propriedade Intelectual. Estudos em Homenagem à Professora Maristela Basso. Curitiba: Juruá, 2005. 
SILVEIRA, Newton. Propriedade Intelectual: propriedade industrial, direito do autor, software, cultivares, nome empresarial, abuso de patentes. 5 ed. Barueri: Manole, 2014.

SIMMA, Bruno; PULKOWSKI, Dirk. Of Planets and the Universe: Self-Contained Regimes in International Law. The European Journal of International Law, v. 17, n. 3, p. 483-529, Jun. 2006.

SIMMONS, Beth; DOBBIN, Frank; GARRETT, Geoffrey. Introduction: the International Diffusion of Liberalism. International Organization, v. 60, n. 4, p. 781-810, Oct. 2006.

SKILLINGTON, G.; SOLOVY, Eric. The Protection of Test and Other Data Required by Article 39.3 of the TRIPS Agreement. Northwestern Journal of International Law and Business, v. 24, n. 1, p. 1-52, Fall 2003.

SOLÍS, Mireya; KATADA, Saori. Explaining FTA Proliferation: A Policy Diffusion Framework. In: SÓLIS, Mireya; STALLINGS, Barbara; KATADA, Saori (Ed.). Competitive Regionalism: FTA Diffusion in the Pacific Rim. Hampshire: Palgrave MacMillian, 2009.

STRANG, David. Adding Social Structure to Diffusion Models: An Event History Framework. Sociological Methods and Research, v. 19, n. 3, p. 324-353, Feb. 1991.

SWISS FEDERAL INSTITUTE OF INTELLECTUAL PROPERTY - IGE/IPI. Supplementary Protection Certificates. Available at: $<$ https://www.ige.ch/en/protectingyour-ip/patents/after-your-patent-has-been-granted/supplementary-protectioncertificates.html>. Accessed on: 18 Oct. 2017.

TANG, Yi Shin; TEODORO, João Paulo. The Politics and Outcomes of Preferential Trade Strategies: Evidence from TRIPS-Plus Provisions in US-Latin American Relations. Journal of World Trade, v. 50, n. 6, p. 1061-1084, Dec. 2016.

TAUBMAN, Antony; WAGER, Hannu; WATAL, Jayashree. A Handbook on the WTO TRIPS Agreement. Cambridge: Cambridge University Press, 2012.

THORSTENSEN, Vera; FERRAZ, Lucas (Coord.). A Multiplicação dos Acordos Preferenciais de Comércio e o Isolamento do Brasil. São Paulo: Instituto de Estudos para o Desenvolvimento Industrial, 2013. Available at: $<$ http://www.iedi.org.br/anexos_legado/51d18e9168afa9d0.pdf $>$. Accessed on: 15 Sep. 2017.

Brazil: Exploring New Paths with the European Union. São Paulo: CCGI, 2015. Available at: $\quad<$ http://ccgi.fgv.br/sites/ccgi.fgv.br/files/file/Publicacoes/Brazil-EUNew\%20paths\%20-\%20VF\%20-\%2015-11-2015.pdf>. Accessed on: 15 Dec. 2017.

THORSTENSEN, Vera; KOTZIAS, Fernanda. Integração Regulatória: uma proposta de Coerência, Convergência e Cooperação para a Modernização do Mercosul. Boletim de Economia e Política Internacional, Brasília, n. 20, p. 21-29, May/Aug. 2015.

THORSTENSEN, Vera; CASTELAN, Daniel; RAMOS, Daniel; MÜLLER, Carolina. Propriedade Intelectual. In: THORSTENSEN, Vera; OLIVEIRA, Ivan (Org.). Os BRICS 
na OMC: políticas comerciais comparadas de Brasil, Rússia, Índia, China e África do Sul. Brasília: IPEA, 2012.

TWINING, William. Diffusion of Law: A Global Perspective. Journal of Comparative Law, v.1, n. 1, p. 237-260, 2006.

2000.

Globalisation and Legal Theory. Evanston: Northwestern University Press,

UNITED NATIONS - UN. 2017 World Economic Situation Prospects. New York: United Nations, 2017. Available at: <https://www.un.org/development/desa/dpad/wpcontent/uploads/sites/45/publication/2017wesp_full_en.pdf $>$. Accessed on 2 Nov. 2017.

Report of the United Nations Secretary-General's High-Level Panel on Access to Medicines: promoting innovation and access to health technologies. September, 2016. Available at: <http://www.unsgaccessmeds.org/final-report/>. Accessed on: 23 Apr. 2017.

UNITED NATIONS EDUCATIONAL, SCIENTIFIC AND CULTURAL ORGANIZATION - UNESCO. Universal Copyright Convention. UNESCO. Available at: $\quad<$ http://www.unesco.org/new/en/culture/themes/creativity/creativeindustries/copyright/universal-copyright-convention/> . Accessed on: 30 Jun. 2017.

UNITED NATIONS COMMISSION ON INTERNATIONAL TRADE LAW UNICITRAL. UNCITRAL Legislative Guide on Secured Transactions: Supplement on Security Rights in Intellectual Property. New York: United Nations, 2011.

UNITED NATIONS CONFERENCE ON TRADE AND DEVELOPMENT - UNCTAD; INTERNATIONAL CENTRE FOR TRADE AND SUSTAINABLE DEVELOPMENT ICTSD. Resource Book on TRIPS and Development: an authoritative and practical guide to the TRIPS Agreement. Cambridge: Cambridge University Press, 2005.

UNITED NATIONS CONFERENCE ON TRADE AND DEVELOPMENT - UNCTAD. About the Intellectual Property Programme Division on Investment and Enterprise. Available at: <http://unctad.org/en/Pages/DIAE/Intellectual\%20Property/About-theProgramme.aspx $>$. Accessed on: 29 Jun. 2017a.

2017 World Investment Report: Investment and the Digital Economy. Available at: <http://unctad.org/en/PublicationsLibrary/wir2017_en.pdf $>$. Accessed on: 10 Jun. $2017 b$.

UNITED NATIONS FRAMEWORK CONVENTION ON CLIMATE CHANGE UNFCCC. Report of the Conference of Parties on its Sixteenth Session, held in Cancun from 29 November to 10 December 2010. Addendum: Part Two: Action taken by the Conference of the Parties at its Sixteenth Session. FCCC/CP/2010/Add.1. Available at: <http://unfccc.int/resource/docs/2010/cop16/eng/07a01.pdf $>$. Accessed on: 26 June 2017.

UNITED STATES FOOD AND DRUG ADMINISTRATION - FDA. What are "biologics"? Question and Answers. Available at: 
$<$ https://www.fda.gov/aboutfda/centersoffices/officeofmedicalproductsandtobacco/cber/uc m133077.htm>. Accessed on: 18 Sep. 2017.

UNITED STATES PATENT AND TRADEMARK OFFICE - USPTO. General Information About 35 U.S.C 161 Plant Patents. Available at: $<$ https://www.uspto.gov/patents-getting-started/patent-basics/types-patentapplications/general-information-about-35-usc-161>. Accessed on: 22 Nov. 2017.

VALDÉS, Raymundo; McCANN, Maegan. Intellectual Property Provisions in Regional Trade Agreements: revision and update. World Trade Organization Economic Research and Statistic Division, Staff Working Paper ERSD-2014-14, p. 1-70, Sep. 2014. Available at: $<$ https://www.wto.org/english/res_e/reser_e/ersd201414_e.pdf $>$. Accessed on: 14 Jan. 2017.

VALDÉS, Raymundo; TAVENGWA, Runyowa. Intellectual Property Provisions in Regional Trade Agreements. World Trade Organization Economic Research and Statistic Division, Staff Working Paper ERSD-2012-21, p. 1-64, Oct. 2012. Available at: $<$ https://www.wto.org/english/res_e/reser_e/ersd201221_e.pdf $>$. Accessed on: 29 May 2017.

VAN DEN BOSSCHE, Peter; ZDOUC, Werner. The Law and Policy of the World Trade Organization. 3 ed. Cambridge University Press: Cambridge, 2013.

VAN LANGENHOVE, Luk. Building Regions: The Regionalization of the World Order. Surrey: Ashgate Publishing Company, 2013.

VÉLEZ, Eduardo. Brazil's Practical Experience with Access and Benefit Sharing and the Protection of Traditional Knowledge. In: WERTH, Alexander; REYES-KNOCHE, Susanne (Ed.). Triggering the Synergies Between Intellectual Property Rights and Biodiversity. Eschborn: GTZ, 2010.

VIVA-EYGUI, David; OLIVA, María Julia. Biodiversity Related Intellectual Property Provisions in Free Trade Agreements. Geneva: ICTSD, 2010.

WATAL, Jayashree. The TRIPS Agreement and Developing Countries: Strong, Weak or Balanced Protection? Journal of World Intellectual Property, v. 1, n. 2, p. 281-307, Mar. 1998.

WORLD CUSTOMS ORGANIZATION - WCO. WCO in Brief. Available at: $<$ http://www.wcoomd.org/en/about-us/what-is-the-wco.aspx>. Accessed on: 2 Apr. 2017a.

. Enforcement and Compliance - Responsibilities: the WCO and the Protection of Intellectual Property Rights (IPR). Available at: $<$ http://www3.wcoomd.org/valelearningoncustomsvaluation_epipr.htm>. Accessed on: 13 Apr. 2017b.

WORLD HEALTH ORGANIZATION - WHO. Public Health, Innovation, Intellectual Property and Trade. Available at: <http://www.who.int/phi/about/en/>. Accessed on: 29 Jun. 2017. 
WORLD HEALTH ORGANIZATION, WORLD INTELLECTUAL PROPERTY ORGANIZATION, WORLD TRADE ORGANIZATION. Promoting Access to Medical Technologies and Innovation: Intersections Between Public Health, Intellectual Property and Trade. Geneva: WTO, 2012.

WORLD INTELLECTUAL PROPERTY ORGANIZATION - WIPO. WIPO Intellectual Property Handbook. 2 ed. Geneva: WIPO, 2004.

2016 World Intellectual Property Indicators. Geneva: WIPO, 2016. Available at: $<$ http://www.wipo.int/edocs/pubdocs/en/wipo_pub_941_2016.pdf $>$. Accessed on: 18 Oct. 2017.

. WIPO Development Agenda. Geneva: WIPO, 2009. Available at: $<$ http://www.wipo.int/edocs/pubdocs/en/general/1015/wipo_pub_11015.pdf $>$. Accessed on: 3 Apr. 2017.

Database on Flexibilities in the Intellectual Property System. Available at: $<\mathrm{http}$ //Www.wipo.int/ip-development/en/agenda/flexibilities/search.jsp $>$. Accessed on: 2 Jun. 2017.

WIPO Handbook on Industrial Property Information and Documentation: $\overline{\text { Terms }}$ and Abbreviations. Geneva: WIPO, 2013. Available at: $<$ http://www.wipo.int/export/sites/www/standards/en/pdf/08-01-01.pdf $>$. Accessed on: 18 Oct. 2017.

WORLD TRADE ORGANIZATION - WTO. 2017 Annual Report. Geneva: WTO, $2017 . \quad$ Available at: $<$ https://www.wto.org/english/res_e/booksp_e/anrep_e/anrep17_e.pdf $>$. Accessed on: 30 Nov. 2017a.

Regional Trade Agreements. Available at: $\overline{<\mathrm{https}}$ //www.wto.org/english/tratop_e/region_e/region_e.htm>. Accessed on: 15 Jun. $2017 \mathrm{~b}$.

The European Union and the WTO. Available at:

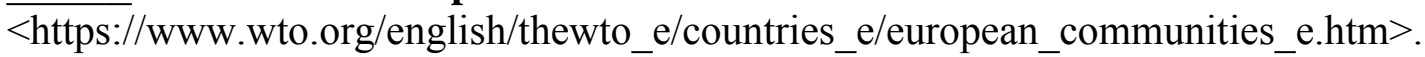
Accessed on: 2 Apr. 2017c.

. TRIPS and Pharmaceutical Patents: Developing countries' Transition Periods.

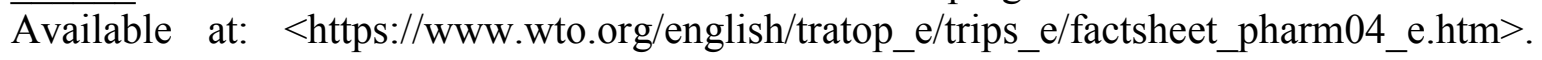
Accessed on: 11 Aug. 2017d.

. Who are the Developing Countries in the WTO? Available at:

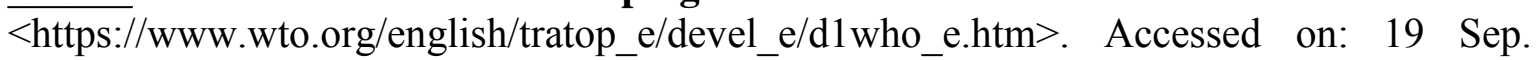
$2017 \mathrm{e}$.

2017 Brazil Trade Policy Review. Available at:

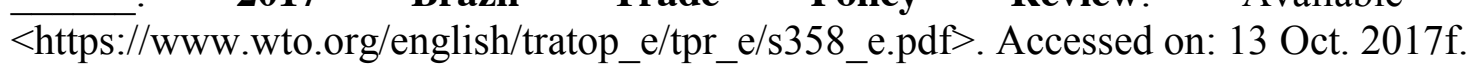


DS199: Brazil - Measures Affecting Patent Protection. Available at:

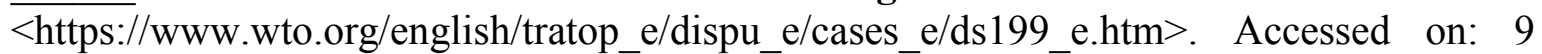
Oct. $2017 \mathrm{~g}$.

. 2016 Morocco Trade Policy Review. Geneva: WTO, 2016. WTO, 2015.

WTO Dispute Settlement One-Page Case Summaries: 1995 - 2014. Geneva: WTO, 2013a.

2013 World Trade Report: factors shaping the future of world trade. Geneva:

2013 European Union Trade Policy Review. Geneva: WTO, 2013 b.

Doha Ministerial Declaration. November 14, 2001. Available at:

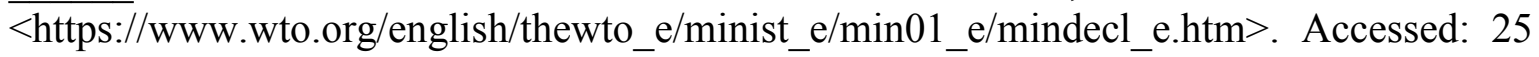
May 2017.

. Council for Trade-Related Aspects of Intellectual Property Rights. Review of article 27.3 (b): communication from Brazil. IP/C/W/228 (24 Nov. 2000). Available at: $<$ https://docs.wto.org/dol2fe/Pages/FE_Search/FE_S_S009-

DP.aspx? language $=$ E\&CatalogueIdList $=41900,39 \overline{5} 2 \overline{5}, 3384,3141,49720,719,3378,3117,15$

$700,559 \&$ CurrentCatalogueIdIndex $=8 \&$ FullTextHash $=\&$ HasEnglishRecord $=$ True $\& H a s F r e$ nchRecord $=$ True \&HasSpanishRecord=True $>$. Accessed on: 12 Jun. 2017.

XIONG, Ping. Patents in TRIPS-Plus Provisions and the Approaches to Interpretation of Free Trade Agreements and TRIPS: Do They Affect Public Health? Journal of World Trade, 46, n.1, p. 155-186, Nov. 2012.

YAMANE, Hiroko. Interpreting TRIPS: Globalisation of Intellectual Property Rights and Access to Medicines. Oxford: Hart Publishing, 2011.

YU, Peter. The Non-Multilateral Approach to International Intellectual Property Norm Setting. In: GERVAIS, Daniel (Ed.). International Intellectual Property: a Handbook of Contemporary Research. Cheltenham: Elgar, 2015.

YU, Peter. The International Enclosure Movement. Indiana Law Journal, v. 82, N. 4, p. 827-907, Fall 2007.

YUSUF, Abdulqawi. TRIPS: Background, Principles and General Provisions. In: CORREA, Carlos; YUSUF, Abdulqawi. Intellectual Property and International Trade: the TRIPS Agreement (Ed.). 3 ed. Alphen aan den Rijn: Kluwer, 2016. 


\section{ANNEX 1 \\ COUNTRY CLASSIFICAITOIN BY WESP}

\begin{tabular}{|l|l|l|l|l|}
\hline \multirow{2}{*}{ North America } & \multicolumn{2}{|c|}{ European Union } & \multirow{2}{*}{ Other Europe } & \multirow{2}{*}{ Asia and Pacific } \\
\cline { 2 - 3 } Canada & Austria & Bulgaria & Iceland & Australia \\
\hline United States & Belgium & Croatia & Norway & Japan \\
\hline & Denmark & Cyprus & Switzerland & New Zealand \\
\hline & Finland & Czech Republic & & \\
\hline & France & Estonia & & \\
\hline & Germany & Hungary & & \\
\hline & Greece & Latvia & & \\
\hline & Ireland & Lithuania & & \\
\hline & Italy & Malta & & \\
\hline & Luxembourg & Poland & & \\
\hline & Netherlands & Romania & & \\
\hline & Portugal & Slovakia & & \\
\hline & Spain & Slovenia & & \\
\hline & Sweden & & & \\
\hline & United Kingdom & & & \\
\hline
\end{tabular}

Source: WESP, 2017, p. 153.

\begin{tabular}{|l|l|l|}
\hline \multicolumn{3}{|c|}{ Economies in Transition } \\
\hline \multicolumn{2}{|c|}{ South-Eastern Europe } & Commonwealth of Independent States and Georgia \\
\hline Albania & Azerbaijan & Republic of Moldova \\
\hline Bosnia and Herzegovina & Belarus & Russian Federation \\
\hline Montenegro & Georgia & Tajikistan \\
\hline Serbia & Kyrgyzstan & Turkmenistan \\
\hline The Former Yugoslav Republic of Macedonia & Uzbekistan \\
\hline
\end{tabular}

Source: WESP, 2017, p. 153. 


\begin{tabular}{|c|c|c|c|}
\hline \multicolumn{4}{|c|}{ Developing Economies } \\
\hline \multicolumn{2}{|c|}{ Africa } & Asia & $\begin{array}{c}\text { Latin America and } \\
\text { Caribbean }\end{array}$ \\
\hline North Africa & Southern Africa & East Asia & Caribbean \\
\hline Algeria & Angola & Brunei Darussalam & Bahamas \\
\hline Egypt & Botswana & Cambodia & Barbados \\
\hline Libya & Lesotho & China & Cuba \\
\hline Mauritania & Malawi & Fiji & Dominican Republic \\
\hline Morocco & Mauritius & Hong Kong SAR & Guyana \\
\hline Sudan & Mozambique & Indonesia & Haiti \\
\hline Tunisia & Namibia & Kiribati & Jamaica \\
\hline Central Africa & South Africa & $\begin{array}{l}\text { Lao People's Democratic } \\
\text { Republic }\end{array}$ & Trinidad and Tobago \\
\hline \multirow{2}{*}{ Cameroon } & Swaziland & Malaysia & \multirow{2}{*}{$\begin{array}{l}\text { Mexico and Central } \\
\text { America }\end{array}$} \\
\hline & Zambia & Mongolia & \\
\hline Central African Republic & Zimbabwe & Myanmar & Belize \\
\hline Chad & West Africa & Papua New Guinea & Costa Rica \\
\hline Congo & Benin & Philippines & El Salvador \\
\hline Equatorial Guinea & Burkina Faso & Republic of Korea & Guatemala \\
\hline Gabon & Cabo Verde & Samoa & Honduras \\
\hline São Tomé and Principe & Côte d'Ivoire & Singapore & Mexico \\
\hline East Africa & Gambia & Solomon Islands & Nicaragua \\
\hline Burundi & Ghana & $\begin{array}{l}\text { Taiwan Province of } \\
\text { China }\end{array}$ & Panama \\
\hline Comoros & Guinea & Thailand & South America \\
\hline $\begin{array}{l}\text { Democratic Republic of } \\
\text { Congo }\end{array}$ & Guinea-Bissau & Timor-Leste & Argentina \\
\hline Djibouti & Liberia & Vanuatu & Bolivia \\
\hline Eritrea & Mali & Viet Nam & Brazil \\
\hline Ethiopia & Niger & South Asia & Chile \\
\hline Kenya & Nigeria & Afghanistan & Colombia \\
\hline Madagascar & Senegal & Bangladesh & Ecuador \\
\hline Rwanda & Sierra Leone & Bhutan & Paraguay \\
\hline Somalia & Togo & India & Peru \\
\hline Uganda & & Iran & Suriname \\
\hline \multirow[t]{18}{*}{$\begin{array}{l}\text { United Republic of } \\
\text { Tanzania }\end{array}$} & & Maldives & Uruguay \\
\hline & & Nepal & Venezuela \\
\hline & & Pakistan & \\
\hline & & Sri Lanka & \\
\hline & & Western Asia & \\
\hline & & Bahrain & \\
\hline & & Iraq & \\
\hline & & Israel & \\
\hline & & Jordan & \\
\hline & & Kuwait & \\
\hline & & Lebanon & \\
\hline & & Oman & \\
\hline & & Qatar & \\
\hline & & Saudi Arabia & \\
\hline & & Syrian Arabic Republic & \\
\hline & & Turkey & \\
\hline & & United Arab Emirates & \\
\hline & & Yemen & \\
\hline
\end{tabular}

Source: WESP, 2017, 154. 